San Jose State University

SJSU ScholarWorks

Master's Theses

Master's Theses and Graduate Research

Fall 2019

\title{
Summer Habitat Used by American Kestrels in Santa Clara \\ County, California
}

Nicole Tomes

San Jose State University

Follow this and additional works at: https://scholarworks.sjsu.edu/etd_theses

\section{Recommended Citation}

Tomes, Nicole, "Summer Habitat Used by American Kestrels in Santa Clara County, California" (2019). Master's Theses. 5085.

DOI: https://doi.org/10.31979/etd.779h-3buy

https://scholarworks.sjsu.edu/etd_theses/5085

This Thesis is brought to you for free and open access by the Master's Theses and Graduate Research at SJSU ScholarWorks. It has been accepted for inclusion in Master's Theses by an authorized administrator of SJSU ScholarWorks. For more information, please contact scholarworks@sjsu.edu. 
SUMMER HABITAT USED BY AMERICAN KESTRELS (FALCO SPARVERIUS) IN SANTA CLARA COUNTY, CALIFORNIA

\author{
A Thesis \\ Presented to \\ The Faculty of the Department of Environmental Studies
}

San José State University

In Partial Fulfillment

of the Requirements for the Degree

Master of Science

by

Nicole Tomes

December 2019 
(C) 2019

Nicole Tomes

\section{ALL RIGHTS RESERVED}


The Designated Thesis Committee Approves the Thesis Titled

SUMMER HABITAT USED BY AMERICAN KESTRELS (FALCO SPARVERIUS) IN SANTA CLARA COUNTY, CALIFORNIA

by

Nicole Tomes

APPROVED FOR THE DEPARTMENT OF ENVIRONMENTAL STUDIES

SAN JOSÉ STATE UNIVERSITY

December 2019

Lynne Trulio, Ph.D

Department of Environmental Studies

Rachel O’Malley, Ph.D D Department of Environmental Studies

Max Tarjan, Ph.D

San Francisco Bay Bird Observatory

Richard M. Kos, AICP Department of Urban and Regional Planning 


\title{
ABSTRACT \\ SUMMER HABITAT USED BY AMERICAN KESTRELS IN SANTA CLARA COUNTY, CALIFORNIA
}

\author{
by Nicole Tomes
}

Urbanization can be a primary source of the loss of native species populations by causing habitat loss, fragmentation and land conversion (Tilman et al., 2001; Krauss et al., 2010; Marzluff, 2001). Birds of prey, which are mid or top carnivores, are especially at risk from the loss of habitat that can occur on both the breeding and wintering grounds. Raptors can be considered environmental indicators of habitat degradation because of their small populations, low population densities, and high position in local food webs. This research investigated the habitat preference of the American Kestrel (Falco sparverius) (kestrel), a widely distributed raptor, whose populations have been declining in the U.S. and may be declining in Santa Clara County in northern California. The land cover and habitat features with which kestrels associated were identified by collecting in situ records of habitat features and conducting point counts of kestrels. Results showed an association between kestrel presence with grassland/shrub/scrub and pasture/hay/crops land cover, especially in open space conditions, indicating that conservation of these habitats could help protect American kestrel populations. Installing more kestrel nest boxes in grassland/shrub/scrub and pasture/hay/crops conditions with strategic monitoring of reproductive success may benefit populations in this region. 


\section{ACKNOWLEDGEMENTS}

I would like to thank several people who have made this thesis possible with their support. Dr. Lynne Trulio guided me through the whole process of this thesis research. Dr. Rachel O’Malley helped me initiate this research by teaching the environmental topics class and assisted me with the statistical analysis. Rick Kos assisted me with ArcMap and allowed me to use resources in the Urban and Regional Planning department. Dr. Max Tarjan from the San Francisco Bay Bird Observatory (SFBBO) helped me develop the analysis. And a special thank you to Lee Pauser for his work on the nest boxes, knowledge of kestrels and allowing me to use the nest box site information.

Finally, I would like to thank my family and friends who always supported my goals, especially my parents who encouraged me to follow my interests, my sister who I could lean on for support during the stressful moments and my husband for moving here with me and being there for me throughout this journey. 


\section{TABLE OF CONTENTS}

List of Tables................................................................ vii

List of Figures.............................................................. viii

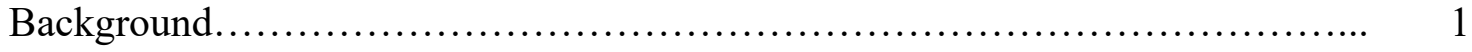

American Kestrel Life History and Ecology ............................... 4

Status and Threats.................................................... 5

Land Use............................................................... 7

Vegetation and Land Cover............................................... 8

Nest Site Selection, Availability and Nest Box Monitoring................... 10

American Kestrel Populations in California............................... 12

Problem Statement................................................. 13

Research Questions.............................................. 14

Hypotheses.......................................................... 15

Methods........................................................................ 16

Study Site and Description............................................ 16

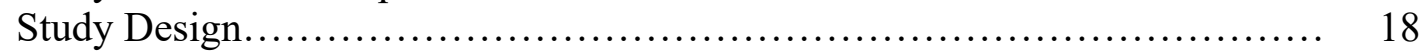

Field Observations .................................................... 23

Geospatial Analysis................................................. 23

Nest Box Monitoring ................................................ 26

Data Analysis......................................................... 29

Results................................................................ 30

Birds of Prey Count and Land Use...................................... $\quad 30$

Kestrel Behavior....................................................... 33

Habitat Types..................................................... 33

Nest Box Habitat Variables......................................... 36

Discussion.................................................................. 38

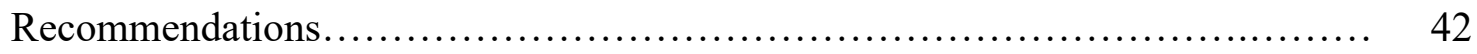

References................................................................ 43

Appendices............................................................... 50

Appendix A: Land Cover Variables.................................. 50

Appendix B: Measured Variables ........................................ 53 


\section{LIST OF TABLES}

Table 1. Descriptive Statistics of Birds of Prey Counts.......................... 23

Table 2. Descriptive Statistics of Kestrel Counts and Behavior................... 33

Table 3. Logistic Regression Analysis of Occupied and Unoccupied Sites.......... 35

Table 4. Mann-Whitney U Analysis of Occupied and Unoccupied Sites............ 35 


\section{LIST OF FIGURES}

Figure 1. Occupied and unoccupied sites (occupied in blue, unoccupied in orange) in Santa Clara County, California................................. 17

Figure 2. Developed land use site \#59 located on Evans Rd. in Milpitas, California.

Figure 3. Agriculture land use site \#19 located on Dougherty Ave. in Morgan Hill, California.

Figure 4. Open space land use site \#79 located in Santa Teresa County Park, California.

Figure 5. Example of an occupied site (blue point) with a $350 \mathrm{~m}$ buffer and associated habitat types.

Figure 6. Nest box site locations with a $350 \mathrm{~m}$ buffer in Santa Clara County, California.

Figure 7. Birds of prey frequency (mean raptors/30 minute observation \pm SE) for agriculture $(n=24)$, open space $(n=72)$, and developed $(n=18)$ land use types.

Figure 8. Occupied sites with the highest kestrel counts during two field surveys combined.

Figure 9. Habitat type percentages (mean \pm SE) for developed, forest, grassland/shrub/scrub, pasture/hay/crops and open water/wetland in occupied sites and unoccupied sites.

Figure 10. Grassland percentage in agriculture $(n=12)$, open space $(n=36)$ and developed $(n=9)$ land uses.

Figure 11. Habitat type percentages (mean $\pm \mathrm{SE}$ ) for developed, forest, grassland/shrub/scrub, pasture/hay/crops and open water/wetland in occupied sites and nest box sites. 


\section{Background}

Habitat loss and habitat fragmentation are two primary causes for the loss of biodiversity around the world (Wilson, 2016; Wu J.G., 2013). Urban development can eliminate large numbers of native species and cause high local extinction rates (Kowarik, 1995; Luniak, 1994; Marzluff, 2001; McKinney, 2002, Vale \& Vale, 1976). Urbanization can endanger species by diminishing resources that are needed to support urban economies and directly replacing the habitat, and it is more ubiquitous in the United States compared to other human activities (Czech, Krausman, \& Devers, 2000). One example regarding agriculture activities that can change the landscape is clearing land for crop production, growing crops, tilling soil and harvesting. Wildlife can experience genetic issues such as inbreeding depression and hybridization as a result of these actions (Czech et al., 2000). Urbanization impacts can last longer than other types of habitat loss such as farming and logging (McKinney, 2002).

Fragmentation of natural landscapes can lead to the reduction in total habitat area and the redistribution of the remaining area into fragments (Wilcove, McLellan \& Dobson, 1986). Studies in severely fragmented landscapes have shown negative effects on bird communities. Island biogeography theory, first developed by MacArthur and Wilson (1967), provides a basic conceptual model for understanding habitat fragmentation. However, there are other factors to consider such as edge effects, modified vegetation surrounding fragments and anthropogenic changes that can influence fragment connectivity (Laurance, 2008). 
In Illinois, Herkert (1994) studied grassland fragments to document the effects of habitat fragmentation and concluded that the fragmentation is likely to have caused Midwestern grassland bird declines, especially for sensitive species. Interactions of fragmentation with climate change, human altered disturbance, species interactions and other drivers of population decline may magnify impacts of fragmentation (Ewers \& Didham, 2005). Avian species are especially sensitive to these dramatic changes in the landscape. Birds of prey may be especially susceptible to the effects of fragmented habitats because of their large home ranges and low densities (Berry, Bock, \& Haire, 1998; Olendorff, 1984).

Land cover change due to urbanization can reduce and degrade avian habitat on local and global scales. Avian population declines were found to be associated with reduced habitat patch size, habitat availability and vegetative complexity and increased non-native vegetation, nest predation and edge in areas where humans have settled (Marzluff, 2001). Urbanization can result in a fragmented habitat, which can also disrupt the ability of a species to spread across a landscape (Wood et al., 2017). For migratory species, changes in either wintering or breeding habitat can also result in population reductions (Dolman \& Sutherland, 1995). Avian species such as raptors that occur at higher trophic levels and have slow life history are more sensitive to anthropogenic threats (Owens \& Bennet, 2000; McClure, Schulwitz, Van Buskirk, Pauli, \& Heath, 2018; Sergio et al., 2008). Results from the McClure (2018) study indicate that globally, 52\% of raptor species are declining and $13 \%$ are threatened compared to all bird species for which $44 \%$ are declining and $13 \%$ are threatened. The most common causes of habitat alteration and 
destruction that affect raptors worldwide are agricultural expansion and logging, according to the Red List assessments (McClure et al., 2018). Rapid urban development has been shown to negatively impact raptor reproductive success through habitat loss, alteration and fragmentation (Berry et al., 1998; Senner \& Cringan, 1989).

Raptors have been considered superior indicators of habitat quality because of their sensitivity to environmental contamination and human disturbance (Estrella, Donazar, \& Hiraldo, 1998; Newton, 1979; Taylor, 1984). Since raptors are considered an apex predator, the population decline of a raptor can indicate a dysfunctional ecosystem assuming that there is a bottom up process (Burnham, Whitacre, \& Jenny,1990; Estrella et al., 1998; Greene, 1988; Newton, 1979; Olendorff, Bibles, Dean, Haugh, \& Kochert, 1989; Terborgh, 1992). Measures of breeding success, such as clutch size, nesting quality and hatching success, can also be used as indicators of environmental quality (Martin, Kitchens, Cattau, \& Oli, 2008; Paviour, 2013; Stout, Temple, \& Papp, 2006).

One raptor that appears to be declining due to habitat degradation and loss is the American kestrel (Falco sparverius). Although American kestrels are common throughout North America, populations have been declining in many regions across North America. Possible reasons for the decline include habitat degradation, predation by Cooper's hawks, effects of the West Nile virus, pesticide use and climate change (Smallwood, et al., 2009). Suitable habitat for kestrels typically include open parkland, agricultural fields, hayfields and meadows (Smallwood \& Bird, 2002).

The Nature Conservancy preserves national and state parks and the growth rate of urban land use in the United States is increasing faster than the land that is being 
preserved by the conservancy (McKinney, 2002). Three states that are considered the most rapidly urbanizing areas are California, Texas and Florida (Czech et al., 2000). While Santa Clara County has habitat that is suitable for kestrels, including farmland, rangeland and open space, open land and agriculture areas are undergoing significant development, and it is unknown whether this conversion of land is affecting local kestrel populations. Kestrel counts and habitat preferences will help resource management specialists to target conservation of critical habitat features and to introduce nest boxes into preferred areas.

\section{American Kestrel Life History and Ecology}

The American kestrel (Falco sparverius) is a diurnal raptor and can be considered a resident of an area or a long-distance migrant in some areas. In North America, kestrels that reside in northerly latitudes migrate to Central America or migrate to the southern U.S. (Smallwood \& Bird, 2002). American kestrels can produce 4-5 egg clutches, laying one egg every other day. Incubation lasts 30 days, beginning with the penultimate egg (Smallwood \& Bird, 2002). The majority of egg laying dates in California have been between April $12^{\text {th }}$ and May $3^{\text {rd }}$. The earliest evidence of nesting in Santa Clara County is March $27^{\text {th }}$ and the latest breeding evidence is on July $27^{\text {th }}$ (Bousman, 2007). Kestrels typically lay one egg every other day until the clutch is complete ( $\mathrm{n}=5$ eggs) (Smallwood $\&$ Bird, 2002). The nesting period of American kestrel lasts 28 days and fledging from the cavity can occur from the $25^{\text {th }}$ day after hatching. They forage on small mammals, birds, insects and lizards (Smallwood \& Bird, 2002). Kestrels are obligate secondary 
cavity nesters that use holes in trees excavated by woodpeckers or other natural manmade cavities (Smallwood \& Bird, 2002).

A radius of 800 meters ( $0.08 \mathrm{ha})$ is the largest known kestrel territory size (Touhiri, Seguey, Imbeau, Mazerolle, \& Bird, 2018). The mean size of kestrel ranges that include nesting territory and peripheral area of use were measured at 129 ha in southern Michigan and 194 ha in Wyoming (Craighead \& Craighead, 1956; Smallwood et al., 2009). In south Florida, territorial kestrels occupied habitats that lacked woody canopy cover and included short grasses and weedy forbes (Smallwood, 1987).

\section{Status and Threats}

American kestrels are considered of "least concern" on the International Union for Conservation of Nature (IUCN) list as of 2016. However, populations in the U.S. have been declining, according to the Breeding Bird Survey from 1984 to 2007 (Smallwood et al., 2009), especially across the interior of western North America and Pacific Northwest (Farmer \& Smith, 2009). Population declines are not the same in all regions and the causes of declines may differ regionally (McClure et al., 2017) (Figure 1). Potential causes of the population decline include the increased populations of Cooper's hawks (Accipiter cooperii) (Farmer et al., 2006), the spread of West Nile virus (WNV), climate change and loss of suitable habitat and tree cavities (Smallwood et al., 2009). However, with respect to WNV, Smallwood et al. (2009) reviewed the trends in the numbers of both resident and migratory kestrel populations that use nest boxes and concluded that all nest box populations in those states had begun to experience declines before the WNV arrived in North America in 1999. Smallwood et al. (2009) found that there were also no 
significant correlations between the decline in kestrel populations densities and an increase in Cooper's hawk populations for the periods of 1966-2007, 1980-2007 in 42 Breeding Bird Survey (BBS) physiographic regions and Christmas Bird Count (CBC) data from 1959-1988.

Smallwood et al. (2009) evaluated habitat quality around nest boxes along the east coast and Canada and results suggested that the habitat surrounding the nest boxes was suitable and those kestrels had high reproductive success. The authors suggest that the principal cause of declines in the eastern U.S. could be losses of birds on the wintering grounds or along migration routes. It was indicated that although the habitat appeared suitable, habitat loss and degradation are important factors that could reduce the number of kestrels that are available to occupy the nest boxes (Smallwood et al., 2009).

Count data collected from the $\mathrm{CBC}$ may indicate a shift in migration patterns and distribution. Heath et al. (2012) used CBC data and North American banding records to examine whether the start of nesting season was associated with the changes in migration patterns that could affect the population counts. They found that males migrated shorter distances than females, while kestrels that nest in northern latitudes migrate longer distances than the southern latitudes. Kestrel migration distance also decreased from 1960-2009 and was negatively associated with winter minimum temperatures. CBC data from the same period showed increasing kestrel abundance in northern states (Washington, Idaho and Utah) where winter minimum temperatures have increased significantly, whereas kestrel abundance has decreased in the southern states (California and Arizona). Warmer winters were found to be a key factor explaining changes in 
nesting phenology of kestrels in southwestern Idaho. The warmer winters can potentially decrease energy demands and allow birds to have shorter migration distances and gain resources for reproduction earlier in the season (Heath, Steenhof, \& Foster, 2012).

\section{Land Use}

American kestrels may be found in different land uses including urban land use. In Boulder, Colorado, American kestrels and red-tailed hawks (Buteo jamaicensis) were the most abundant breeding and wintering diurnal raptors and neither appeared to be sensitive to levels of urbanization up to $30 \%$ of urban land use cover which included developed areas (pavement, buildings) and urban vegetation (Berry et al., 1998). The researchers noted that the urban open space grasslands could support significant populations of birds of prey as long as prey populations persevere; however, they recommended the study be replicated in other areas.

In Baja California Sur, kestrels were positively influenced by urban areas that still hold natural habitats due to potential food, nesting structures and protection from predators; however, caution should be used because of the interaction with European starlings and house sparrows which may reduce the benefits of those habitats. Further land use change may also reduce the benefits (Estrella, 2007).

Although kestrels may use urban areas, human disturbance from urban land use can have negative repercussions for reproduction. Corticosterone (CORT) concentrations and nest abandonment were examined to identify stress-induced reproductive failure. Female kestrels in higher disturbance areas had higher cortisol levels and were more likely to abandon nests than females in lower human disturbance areas. In particular, the proximity 
to the busy roads and developed areas negatively affected kestrel reproduction by causing increased stress hormones that promoted nest abandonment. The results of this study demonstrated that the presence of a species in human-dominated landscapes does not indicate tolerance for anthropogenic stressors (Strasser \& Heath, 2013). Human activities, such as land use change, recreation and urbanization can interact with climate change to affect species abundance, distributions and phenology (Pautasso, 2012).

\section{Vegetation and Land Cover}

Land cover and vegetation are key factors in habitat selection by raptors due to their influence on prey diversity and abundance (Rullman \& Marzluff, 2014). In particular, shorter vegetation increases prey detectability, leading kestrels to prefer disturbed, shortgrass habitats, such as grazed, mowed, or harvested areas (Toland, 1987). This preference for hunting in short vegetation was evident in south central Florida, where migrant kestrels used hunting substrate that consisted of weedy forbes that are $<25 \mathrm{~cm}$ in height and short grasses. By choosing territories in habitats with shorter grasses, including citrus groves, mowed, hayfields, and pastures, females spent less time foraging than males (Smallwood, 1987). Similarly, Best (1986) concluded that occupying habitats characterized by low vegetation cover, even vastly different habitats, increased survival rate and reproductive success because all species optimized their foraging activity in open areas. Brouse (1999) found kestrel numbers in Utah to be highest in irrigated pastures, dry cropland and rural residential habitats compared to native grassland, open water, urban, marsh and river floodplain. 
Kestrels are also found in agricultural land cover types. In south Florida, kestrels were more abundant in agricultural cover than natural land cover types (Pearlstine, Mazzotti, \& Kelly, 2006). Kestrels were found in agricultural habitat $87 \%$ of the time and used powerlines almost exclusively as perches compared to natural perches. In northwestern Quebec, the probability of a kestrel using a nesting site increased with the amount of extensive agricultural lands within $800 \mathrm{~m}$ radius. Kestrels were attracted by meadows and pastures destined for farming in early spring when selecting their nesting habitat. However, the hatching and fledgling periods coincided with the hay harvesting period which could reduce the availability of prey and disturb the kestrels hunting success and parental care (Touhiri et al., 2019). In Southwestern Idaho, Smith, Steenhof, McClure and Heath (2016) found that earlier prey availability in irrigated land shifted the distribution of American kestrels. The higher prey quality on the irrigated land may have led to the kestrel preference of this land cover. The start of growing season in irrigated lands shifted because farmers started planting crops earlier after warmer winters.

In Finland, voles were found to be the primary prey items and the overall reproductive success of kestrels was greater in small farmland areas (size $0.1-10 \mathrm{~km}^{2}$ ) than in large farmland $(100 \mathrm{~km} 2)$. Small farmlands contained the suitable habitat characteristics for a sufficient amount of alternative prey for kestrels such as small birds, shrews, and voles (Valkama. Korpomaki, \& Tolonen, 1995). Results from this study suggest that agricultural fields are important because voles were present. The years with a good number of voles had higher kestrel breeding densities and reproductive success than in years with lower than average vole populations (Korpimäki 1984, 1986, Korpimäki \& 
Norrdahl, 1991). Kestrel population declines in Finland may be associated with changes in farming methods and a decline in vole numbers.

\section{Nest Site Selection, Availability and Nest Box Monitoring}

Nest site selection and availability can affect the fitness and habitat selection of birds (Kruger, 2002). American kestrel breeding habitat selection and territory size varies and is dependent upon habitat quality (prey abundance and nest-site availability) (Bird \& Palmer, 1988; Smallwood et al., 2009). Many local populations are nest site limited because of the loss of secondary cavities (Cade, 1982; Smallwood \& Bird, 2002; Smallwood et al., 2009). Kestrels will accept wooden nest boxes as a substitute for natural nesting cavities (Bird \& Palmer, 1988; Smallwood et al., 2009). In California, kestrels may have declined in part due to loss of suitable nesting trees (Beedy \& Pandolfino, 2013).

Nest boxes placed in open areas with short vegetation with suitable foraging habitat can increase the availability of nest sites, therefore, potentially increase breeding bird numbers (Smallwood, 1987; Smallwood et al., 2009). Nest boxes are artificial nest sites that have been created by humans to aid in conservation management for birds. They may be beneficial when natural cavities are limited, and they may allow researchers or managers to monitor breeding success. Nest boxes have been used frequently to understand the reproductive success and breeding ecology of American kestrels (McClure et al., 2017). Some qualities that researchers look for when monitoring are the egg stages, age of nestlings and drivers of nest success. Nests containing nestlings greater than twenty-two days old are considered to be successful (Steenhof \& Peterson, 2009). 
Kestrels will use nest boxes in areas with ideal hunting habitat and these human-supplied nesting cavities can potentially increase local kestrel populations (Smallwood \& Collopy, 2009). In New Jersey, Smallwood et al. (2009) examined land use and land cover surrounding nest boxes at $1 \mathrm{~km}$ squared circle plots. Boxes occupied by kestrels were associated with significantly greater cropland and pastureland and herbaceous vegetation and less closed deciduous forest than the nest boxes not occupied by kestrels.

American kestrels also responded to an increase in the availability of nest cavities in north central Florida in 2008 (Smallwood \& Collopy, 2009). Smallwood and Collopy (2009) provided nest boxes from 1989-1993 and studied the effect on a local population of threatened Southeastern American kestrels. The kestrels preferred nest boxes in sandhill habitats over those in hammock habitats and nesting attempts in sandhills had greater hatching rates, more fledglings produced and greater overall nesting success. Sites that were chosen by kestrels had more Longleaf pine (Pinus palustris), Cabbage palm (Sabal palmetto) and ground cover ( $<10 \mathrm{~cm}$ in height) as well as fewer broadleaf deciduous trees, oaks (Quercus spp), roadside berms, hayfields, water, and gravel than the sites with nest boxes that were not used by kestrels (Smallwood \& Collopy, 2009).

Shave and Lindell (2017) found that high rates of nesting attempts and nesting success in the orchard nest boxes may result from the placement in suitable habitat which was away from forested areas and near open fields, pastures or row crops in Michigan. The kestrels using the nest boxes had high reproductive rates, indicating that orchards and surrounding areas provide suitable habitat for successful kestrel breeding and fledgling production. The boxes have the potential to sustain or increase the breeding kestrel 
population in the region while also increasing kestrel predation of crop-damaging prey in and around cherry orchards.

While nest box programs may be beneficial, they can also be detrimental to populations if they are placed in low quality habitat and the installation of boxes are not monitored or maintained (McClure et al., 2017). Although reproduction may be successful, habitat quality may still be low (Shave \& Lindell, 2017). Some human dominated landscapes could be an ecological traps or population sinks by providing high prey availability (for example, along roadsides) but then expose birds to increased mortality and disturbance due to human disturbance (road traffic) (Strasser \& Heath, 2013).

\section{American Kestrel Populations in California}

Habitat loss, fragmentation and degradation have been considered the most important factors in the decline of avian populations (Smallwood et al., 2009). California land use has dramatically changed from agricultural land to urban development since the 1980s and the Central Valley has converted agricultural land to urban areas at a rate higher than any other region of the U.S. (Pandolfino. Herzog, Hooper, \& Smith, 2011). Starting in the 1980s, large areas of cattle ranching have been converted to more intensive agricultural practices such as vineyards and orchards (Pandolfino et al., 2011).

In Santa Clara County, the American kestrel is a common resident wherever there are suitable grasslands, pastures or other open spaces. They favor grasslands, pastures, oak savannas, weedy fields, mixed areas of shrubs and brushlands and typically seek small trees/shrubs, poles, wires or fence posts to perch on and fly from to locate prey 
(Bousman, 2007). They can also be found foraging in suburban/urban areas and avoid woodlands where the understory is more developed. Nests have been previously found in Western sycamore (Platanus racemose) trees and valley oak (Quercus lobate) trees and are less commonly found in woodpecker holes and artificial nest sites (Bousman, 2009). While kestrels are still common throughout the Diablo Range, in eastern foothills of Santa Cruz mountains and on the Santa Clara valley floor, the Breeding Bird Atlas states that there has been a long-term decline of approximately 1.6-3.3\% per year in Santa Clara County as reflected in local CBC counts. Given the kestrel's preference for open shortgrass habitat, the conversion of agriculture and grassland to urban development is likely to reduce kestrel habitat. However, it is unknown if this conversion is linked to regional population declines (Bousman, 2007).

\section{Problem Statement}

There is a concern about the decline of American kestrel (Falco sparverius) populations across the United States. In California, American kestrels are not a protected species, although they may be declining according to the CBC data and Breeding Bird Survey data (Bousman, 2007). Shuford (1993) considered the kestrel an uncommon breeder in Marin County and hypothesized that an absence of available nests may limit the species population there. Roberson (1993) found the American kestrel to be a common resident in Monterey County, but declines have been caused by loss of oak woodlands and riparian forests to agriculture and development. Long term declines noted locally in this county has no obvious explanation. There doesn't appear to be an absence of large trees with natural cavities suitable for nesting. Similar declines have not been 
observed for other common raptors such as the white-tailed kite and red-tailed hawk. With a human population of 7,654,870 in 2016, the San Francisco Bay Area is the fifth most densely inhabited metropolitan area in the U.S. (Grossinger, Striplen, Askevold, Brewster, \& Beller, 2007, Wood et al., 2017). As the human population has increased, the San Francisco Bay Area has become more urbanized with associated losses of habitat and open space for wildlife (Pandolfino, 2011).

While habitat preferences of kestrels have been documented in a number of locations, kestrel breeding habitat in Santa Clara County has not been characterized. In addition, although kestrels are found in developed, agricultural and open space lands, potential differences in habitat qualities between these land uses has not been assessed. Such information may help managers protect this species in the face of advancing urbanization. This study analyzed quantitative data to assess features of habitat at sites occupied by kestrels, unoccupied sites and at nest box locations in Santa Clara County. The following research questions and hypotheses were addressed:

\section{Research Questions}

RQ1: What is the abundance of birds of prey at American kestrel occupied and unoccupied sites and is there a difference in the frequency between occupied and unoccupied sites?

RQ2: What perch types are used and what is the general behavior of American kestrels?

RQ3: What habitat features and habitat types are associated with American kestrel occupied sites during the breeding season in Santa Clara County? 
RQ4: How does the percent cover of different habitat types compare between nest box sites and other occupied kestrel sites?

\section{Hypotheses}

Ho1: Among the three general plan land use types sampled in the study, "developed," “agriculture," or "open space."

Ho1a: The frequency of birds of prey does not differ.

Ho1b: The percent of grassland/shrub/scrub does not differ. 


\section{Methods}

\section{Study Site and Description}

This study was conducted within Santa Clara County in northern California, in

proximity to the San Francisco Bay (Bay Area) (Figure 1). This region experiences a Mediterranean climate characterized by mild rainy winters and warm to hot summers and includes a range of various plant communities, microclimates and elevations (Frey et al., 2017). Historically, perennial grasses dominated interior and coastal grasslands; however, invasive annual grasses are now the dominant species, supported by anthropogenic disturbances such as over-grazing, agriculture and brush clearing.

The counties within the Bay Area have experienced significant widespread development on the landscape (Dowall, 1984). Before the 1950s, traditional land use consisted of agricultural land east of Oakland and to the north and south of San Francisco. After World War II, this area experienced a rapid change in land use and an influx of technology firms into the South San Francisco Bay Area. Growth intensified starting in the 1980s, especially in Santa Clara County, where orchards, agricultural lands, open grasslands and woodlands were lost to urbanization such as commercial and residential land uses (Potter, 2015). 


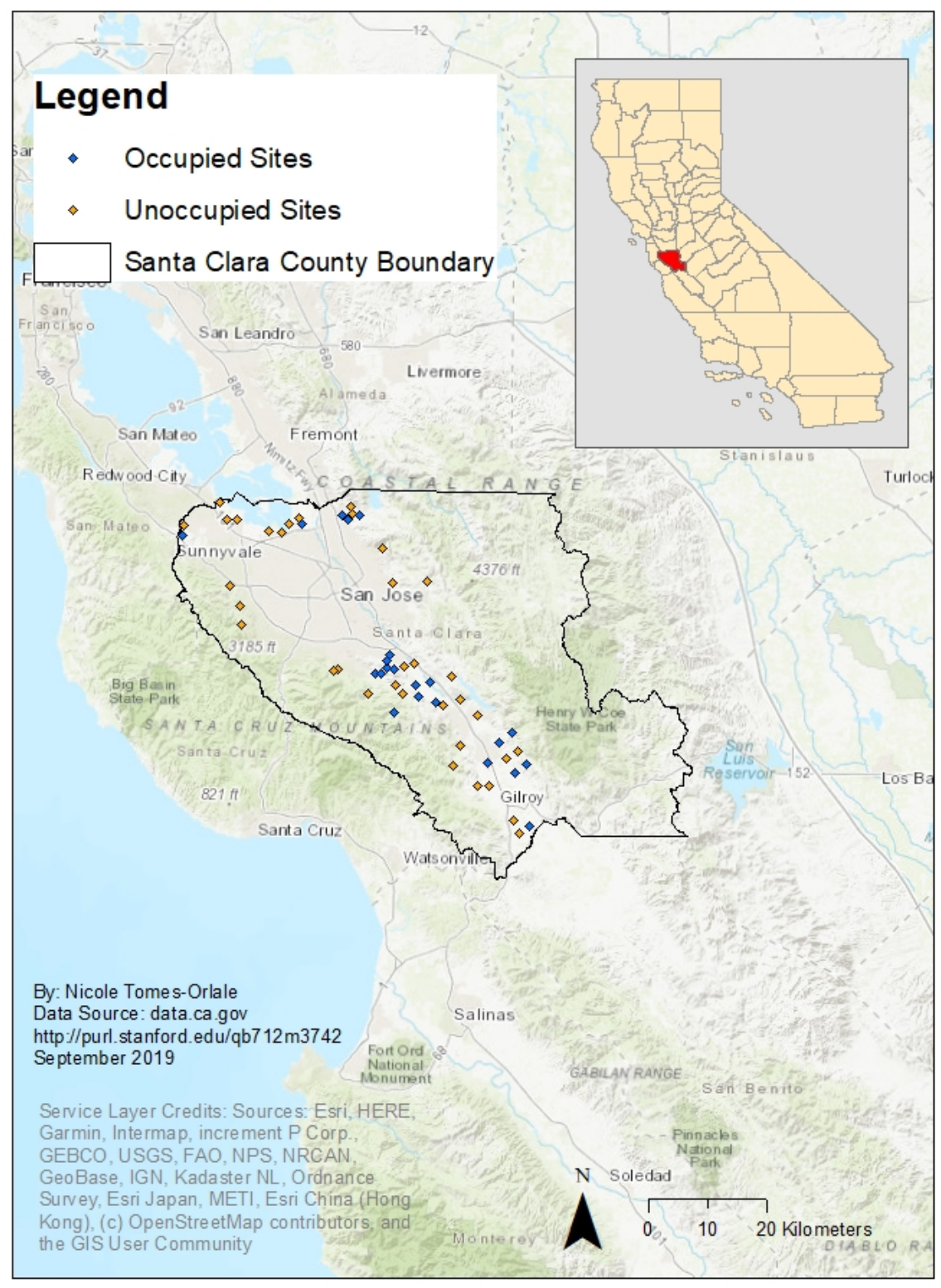

Figure 1. Occupied and unoccupied sites (occupied in blue, unoccupied in orange) in Santa Clara County, California. 


\section{Study Design}

This study used field observations and a GIS analysis of land cover data to assess the characteristics of habitat used in the summer by American kestrels. E-Bird is a public access website for citizen scientists to record bird counts. Field study sites were chosen by using 2016-2017 eBird sites in March-August. Repetitive sites were chosen using GIS random selection tool from land uses that included: public lands, regional parks, rural residential, bayland, and educational institutions in GIS. The constraining feature class was the boundary of each land use, "field" was the number of points for each polygon and the "linear unit" was the minimum distance between the points which was at least $700 \mathrm{~m}$ apart. Points that were not accessible or in private areas were eliminated, resulting in 60 total survey points (30 eBird and 30 random).

Point count surveys began on May 27, 2018 and continued until August 7, 2018. The majority of surveys (79\%) were conducted in June and July during a time when kestrels are most likely to be seen, as most kestrels have hatched and can therefore be detected. Shave and Lindell (2017) found that kestrels hunt throughout the day; thus, the earliest start time for this study was 07:30 and the latest end time was 14:40 PST. This is supported by previous observations that kestrels hunt throughout the day without apparent peaks in activity (Shave \& Lindell, 2017).

I visited 1-3 occupied kestrel locations per week and each occupied and control site was visited twice during the 2018 breeding season. The second round of surveys was done at least 28 days after the first round. A location was considered occupied if any of the following kestrel behaviors were observed at least once during the season: (1) 
territorial behavior, (2) hovering and foraging behavior, (3) perching. During each visit, a 30-minute observation of kestrel behavior and habitat characteristics was done. Weather (temperature, wind speed) and habitat characteristics such as percent vegetation cover which included percent low shrub, percent high shrub, percent grassland, percent agriculture, percent marsh, percent riparian, and percent other, which was estimated in the field within $250 \mathrm{~m}$, were collected in the first 5 minutes of the observation. Field notes were compared to the national land cover results within each buffer calculated in the GIS analysis. Land use for each site was recorded and separated into three categories, developed (Figure 2), agricultural (Figure 3) and open space (Figure 4). During the next 25 minutes, the entire area was scanned within $250 \mathrm{~m}$ at 5 -minute intervals using $8 \mathrm{X} 42$ Nikon Prostaff 7s binoculars and a Nikon spotter XLII scope. Any bird of prey or adult/juvenile kestrel seen within $250 \mathrm{~m}$ of the data point was recorded. Survey points were at least $0.7 \mathrm{~km}$ apart due to home ranges that vary between $0.5 \mathrm{~km}-2.4 \mathrm{~km}$ in diameter. 


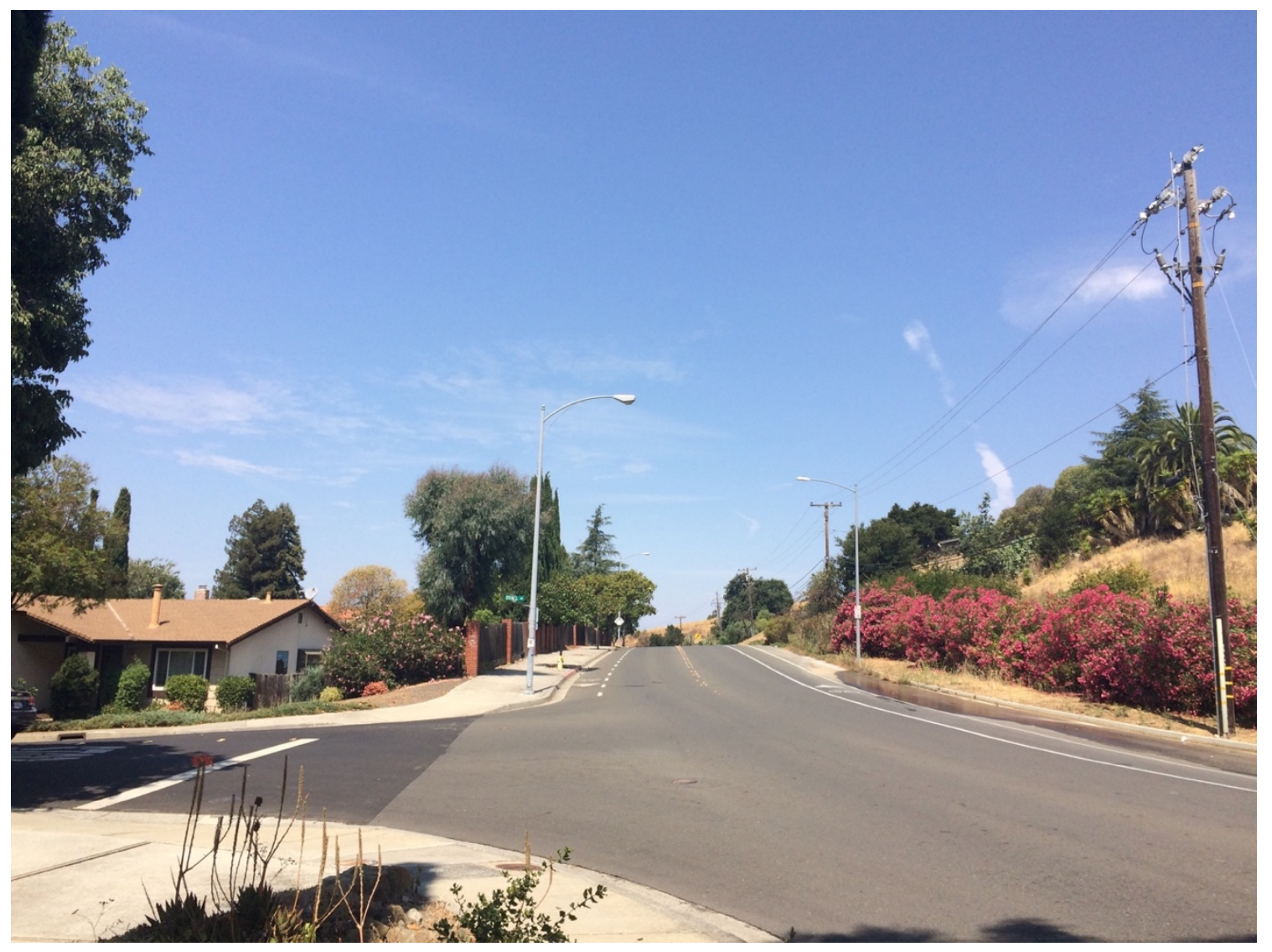

Figure 2. Developed land use site \#59 located on Evans Rd. in Milpitas, California. 


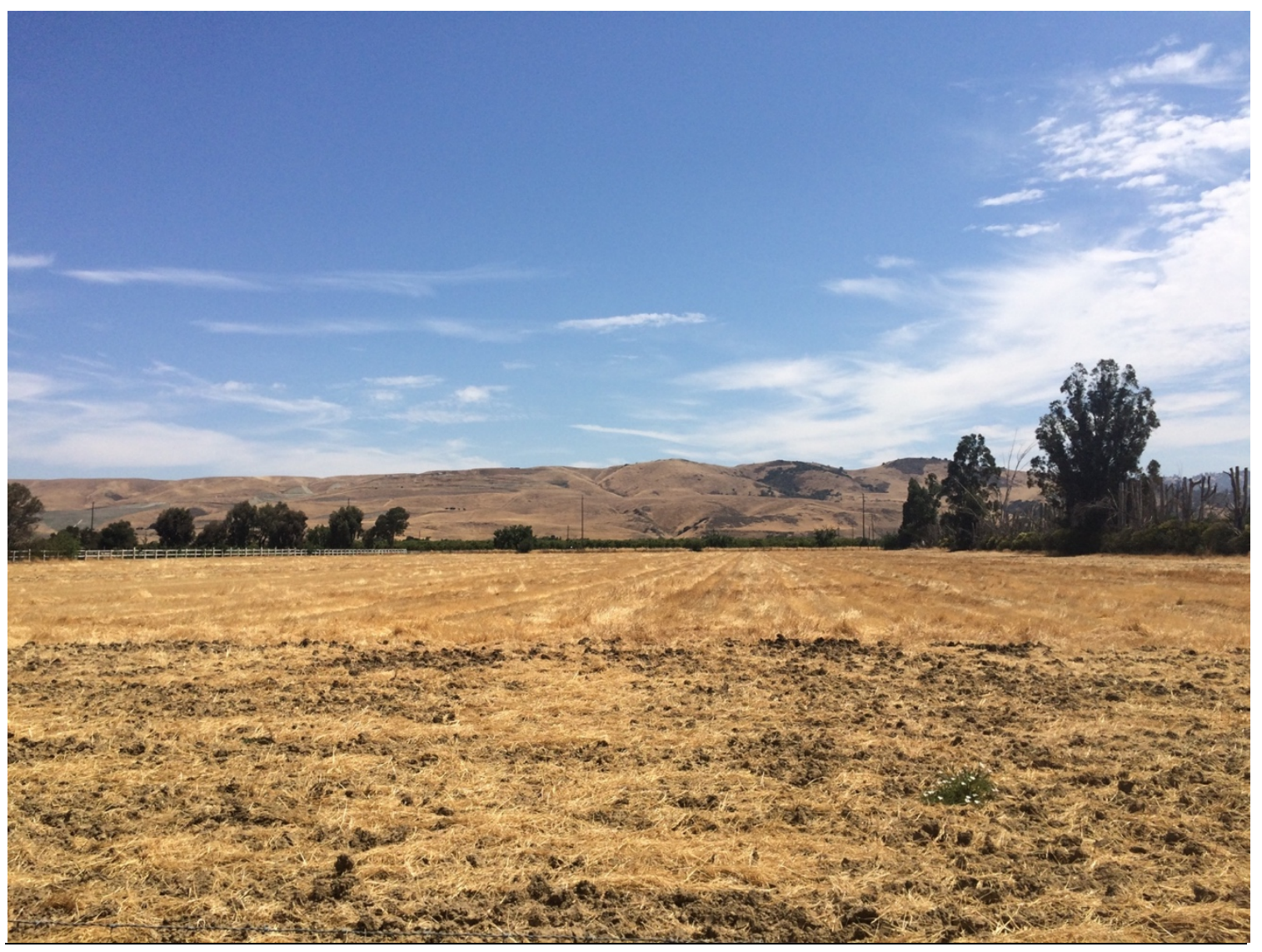

Figure 3. Agriculture land use site \#19 located on Dougherty Ave. in Morgan Hill, California. 


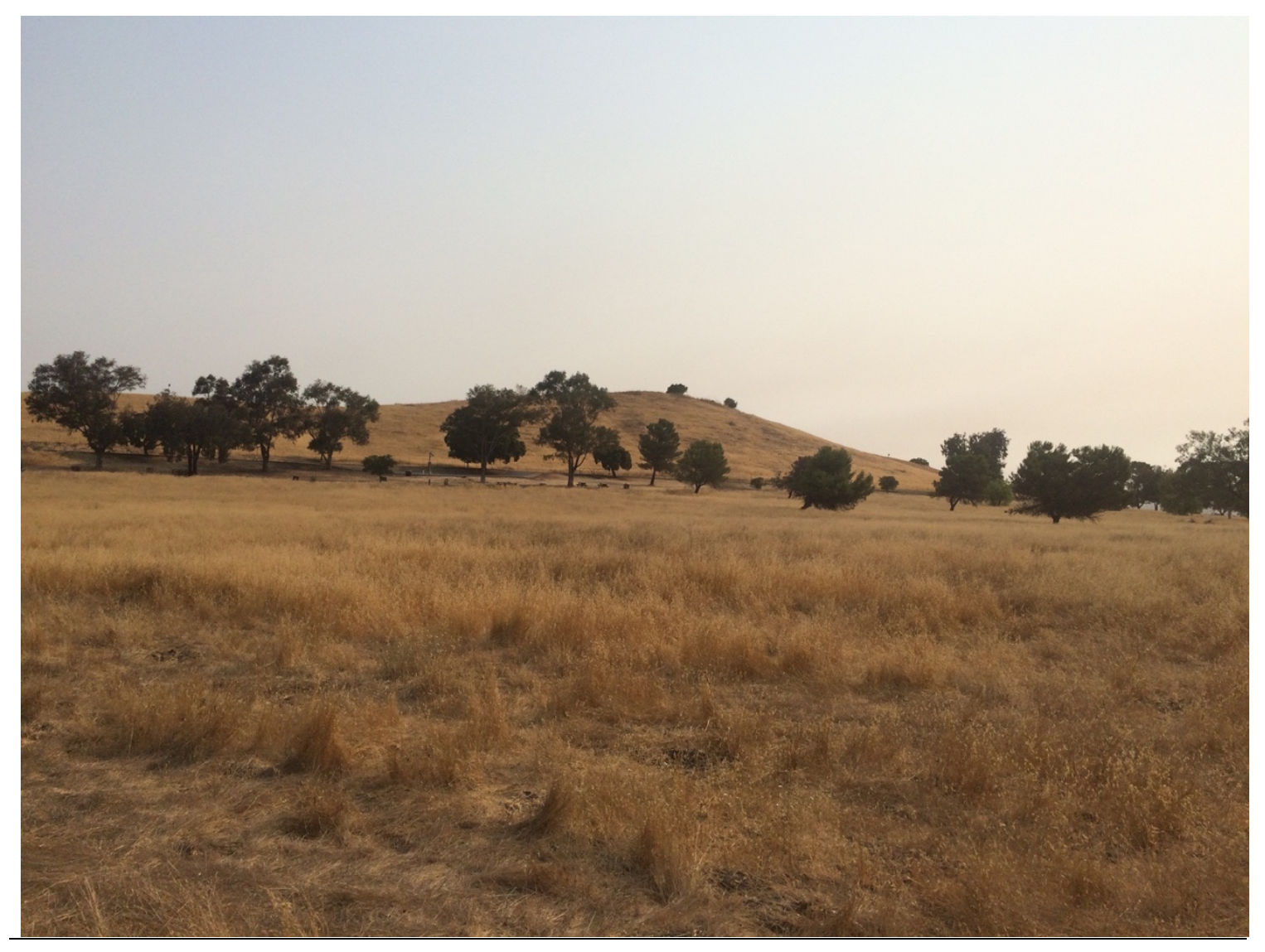

Figure 4. Open space land use site \#79 located in Santa Teresa County Park, California. 


\section{Field Observations}

A total of 57 sites were visited, 22 sites where kestrels were present (occupied) and 35 sites where kestrels were absent (unoccupied), for 30 minutes each. Each site was visited twice (except one site that was closed during the second survey), for a total of 113 site visits, and a total of approximately 57 hours of observation time. Combining all sites, 206 birds of prey of five taxa were observed (Table 1).

Table 1

Descriptive Statistics of Birds of Prey Counts

\begin{tabular}{|c|c|c|c|c|c|}
\hline $\begin{array}{l}\text { Kestrel } \\
\text { Presence }\end{array}$ & $\begin{array}{l}\text { Turkey } \\
\text { Vulture } \\
\text { (Cathartes } \\
\text { aura) }\end{array}$ & $\begin{array}{l}\text { Red-tailed } \\
\text { Hawk (Buteo } \\
\text { jamaicensis) }\end{array}$ & $\begin{array}{l}\text { Red- } \\
\text { shouldered } \\
\text { Hawk } \\
\text { (Buteo } \\
\text { lineatus) }\end{array}$ & $\begin{array}{l}\text { White- } \\
\text { tailed Kite } \\
\text { (Elanus } \\
\text { leucurus) }\end{array}$ & Unknown \\
\hline Occupied & 49 & 20 & 4 & 2 & 0 \\
\hline Unoccupied & 86 & 28 & 4 & 7 & 6 \\
\hline Total & 135 & 48 & 8 & 9 & 6 \\
\hline
\end{tabular}

Note. Frequency of birds of prey and type observed in kestrel occupied and unoccupied sites.

\section{Geospatial Analysis}

Land use and habitat variables from the National Land Cover Database were analyzed in ArcMap 10.5. A diameter buffer of $0.7 \mathrm{~km}$ was used around each kestrel location or control location to maintain independence between sites (Figure 5). NAD83 California State Plane III (linear units in meters) was used as the projected coordinate system. The "Extract by mask" function was used to clip the land cover raster data to the polygons and the "Tabulate Area" function was used to calculate the area and percentage of habitat type in each buffer. 
For each land use type, sites were assigned to these categories using the national land cover database. The land use categories of developed, open space and agriculture were used and generalized from the NLCD 2011 Land Cover classifications. Developed consisted of land cover within low, medium or high developed areas; agriculture was considered pasture, hay or cultivated crops and open space was considered grassland, shrub/scrub, wetland, (emergent, herbaceous), and forest (mixed, evergreen). 


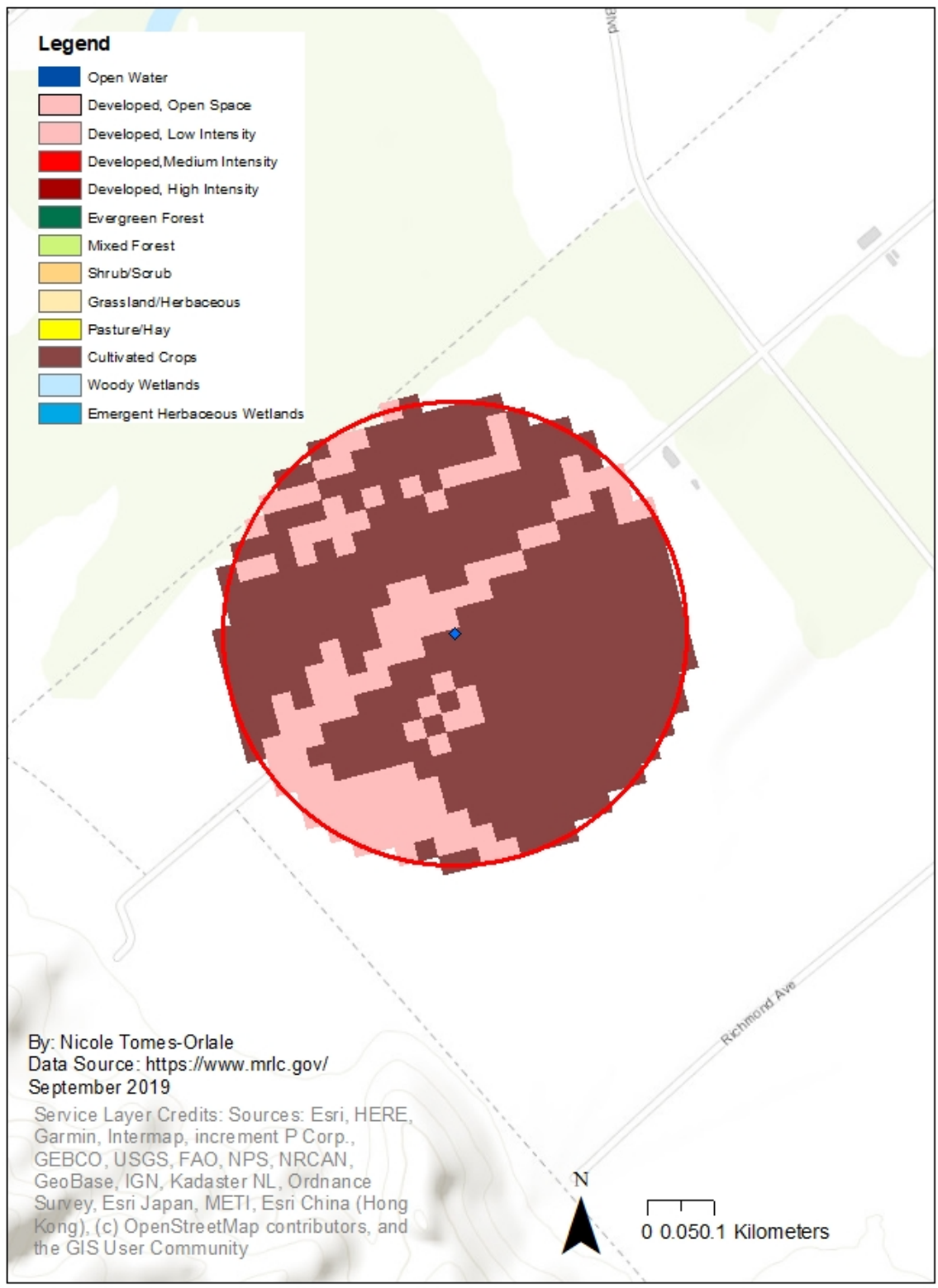

Figure 5. Example of an occupied site (blue point) with a $350 \mathrm{~m}$ buffer and associated habitat types. 
Habitat types used in the GIS analysis include developed (low, medium, high), grassland/shrub/scrub, wetland, (emergent, herbaceous), forest (mixed, evergreen), pasture/hay (cultivated crops). The classification system used by National Land Cover Database 2011 is modified from the Anderson Land Cover Classification System. The land cover types found in this study are described in Appendix A. Open water and wetland were combined, and shrub/scrub and grassland were added together for the analysis. All forest categories were combined, and pasture, hay and crops were combined. The mean percent cover was calculated for occupied and unoccupied sites. The percentage was calculated by adding the meters in each category for the total meters squared then divided by the total of each category of land cover. Distance to nearest road was calculated using the measure tool in ArcMap and included avenues, boulevards, roads, and lanes. Elevation for kestrel presence was found in Google Earth in feet by using the cursor on each kestrel presence site which calculates the elevation. All calculations are totaled in Appendix B.

\section{Nest Box Monitoring}

Lee Pauser, a volunteer of the Audubon Society, has built, installed, and monitored nest boxes for 17 nesting seasons. Pauser is also a member of the Santa Clara Valley Audubon Society (SCVAS), and North American Bluebird Society (NABS). He collected data during the 2018 nesting season and provided results to the California Bluebird Recovery Program (CBRP), and Cornell Lab of Ornithology's NestWatch Program.

He installed nest boxes at Santa Teresa County Park, IBM's Almaden Research Center, Cinnabar Hills Golf Club, and Guadalupe Oak Grove Park. The locations of 9 
large nest boxes were used in this research to assess land use and habitat types around these sites compared to the kestrel locations (control sites) I monitored in summer 2018 (Figure 6). 


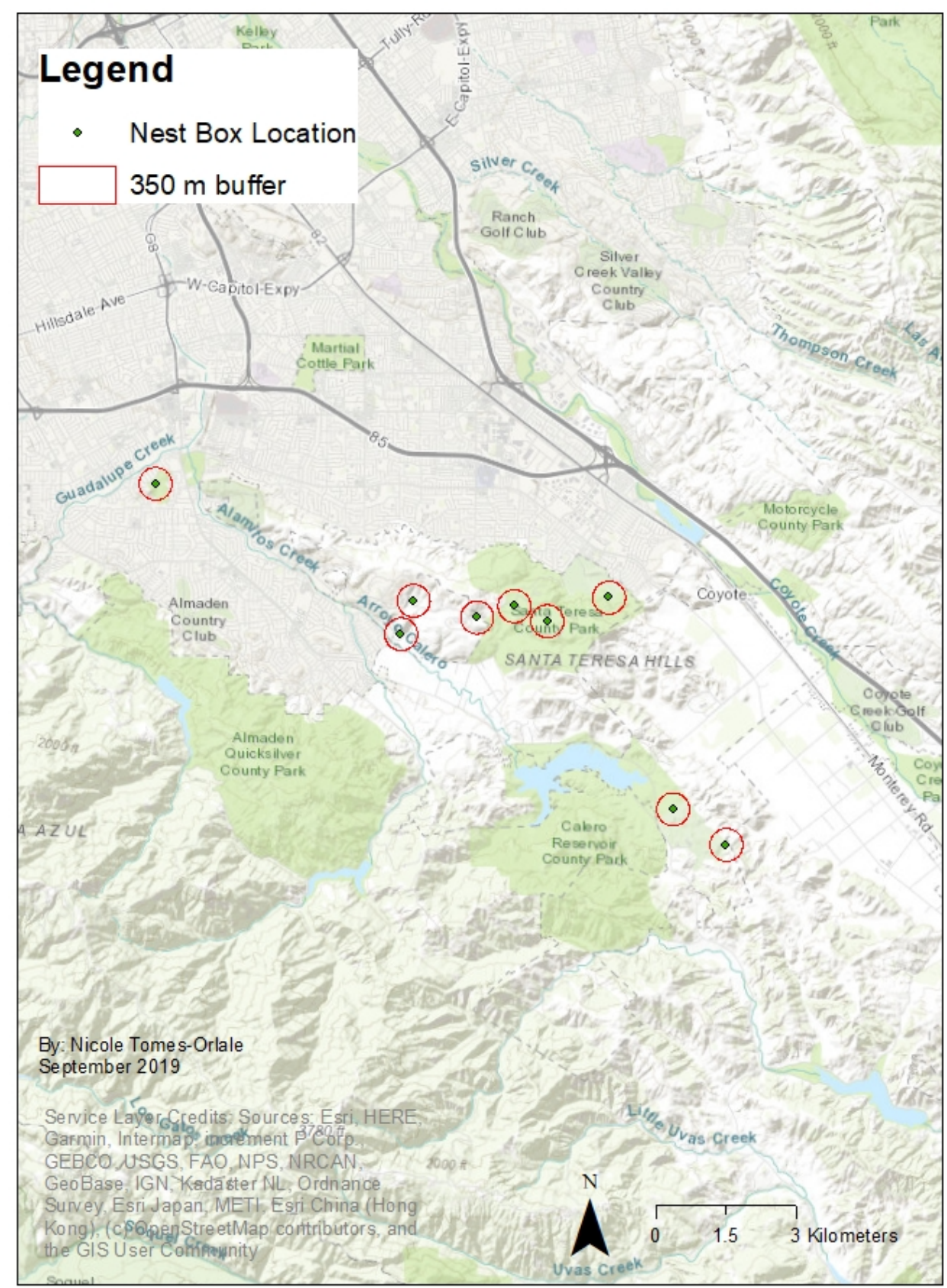

Figure 6. Nest box site locations with a $350 \mathrm{~m}$ buffer in Santa Clara County, California. 


\section{Data Analysis}

Descriptive statistics were used for the number of birds of prey counted, kestrel behavior, perch type, kestrel count and behavior within each land use and the highest kestrel counts. The mean and standard error of the percent habitat type in occupied, unoccupied and nest box sites were calculated. The sites with kestrels were compared to the sites without kestrels to identify any significant differences between the habitat types. The occupied sites were compared to the nest box site locations to identify the habitat variables that kestrels prefer versus the habitat that boxes were placed in. This was compared to see if the nest box sites will attract more kestrels and where to place more boxes in the future.

Statistical tests were conducted using IBM SPSS. To analyze whether the frequency of birds of prey differed between occupied and unoccupied sites, a Mann-Whitney U test was used. A Kruskal-Wallis test was used to assess the difference in the number of predators between three land use types. A correlation analysis was completed before a logistic regression to eliminate habitat variables that were too similar. A logistic regression was used to create a model of significant kestrel habitat features. A MannWhitney $U$ test was used to test the difference in the percent of habitat types between occupied and unoccupied sites. A Kruskal-Wallis test was used to test whether there as a difference in the percent of key habitat types between the three land use types. 


\section{Results}

\section{Birds of Prey Count and Land Use}

Overall, birds of prey numbers did not differ between occupied $(\bar{X}=0.708$,

S.E. $= \pm 0.143, \mathrm{~N}=44.000)$ and unoccupied $(\bar{X}=0.814, \mathrm{~S} . \mathrm{E} .= \pm 0.123, \mathrm{~N}=70.000)$ sites

(Mann-Whitney $U=1,572.000 ; p=0.834, d f=1$ ). Sites in the study with "developed" land use, however, had significantly more birds of prey than "open space" or "agricultural" land use sites (Kruskal-Wallis Statistic $=10.506, \mathrm{df}=2, \mathrm{p}=0.005)($ Table 1 and Figure 7$)$.

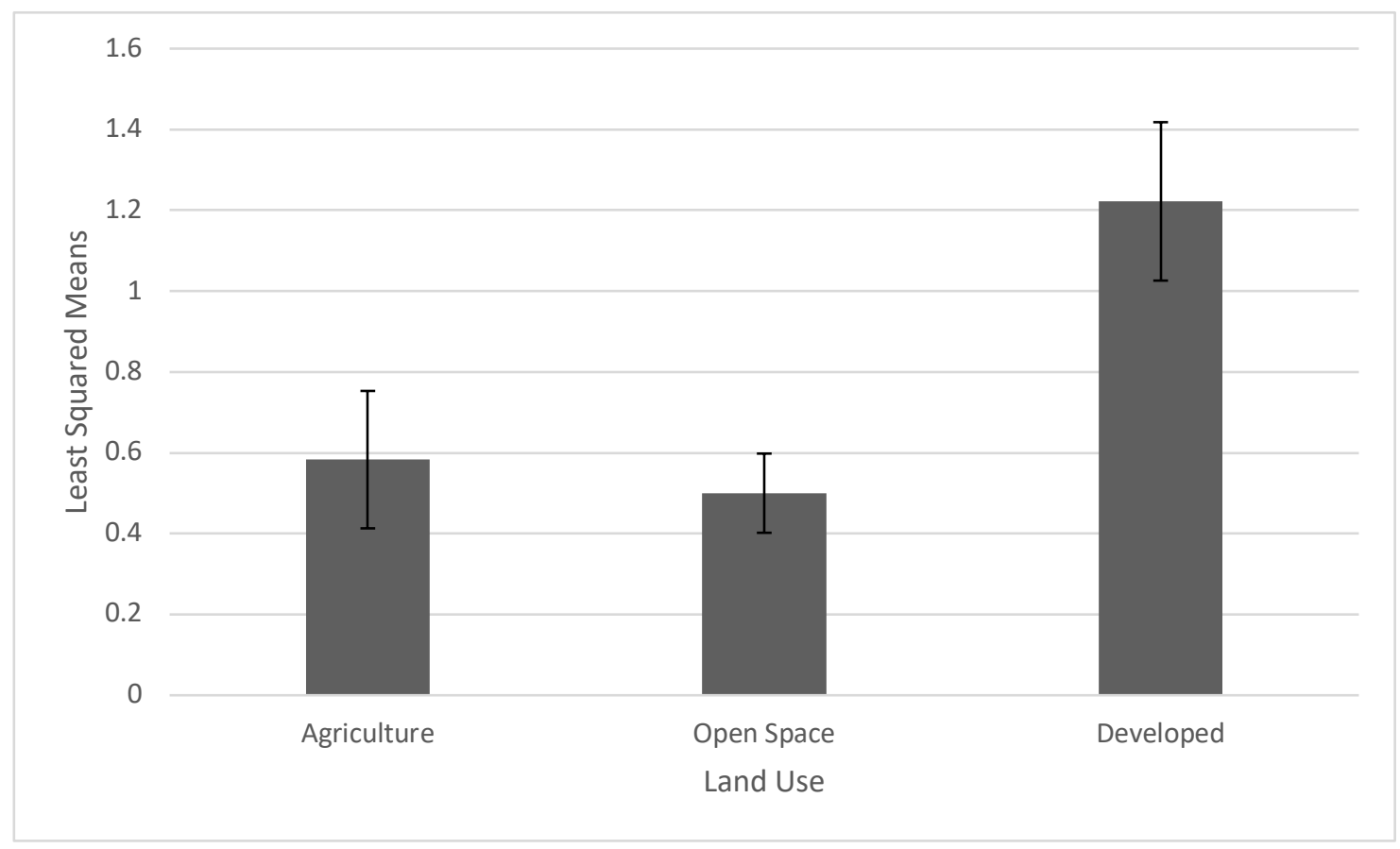

Figure 7. Birds of prey frequency (mean raptors/30 minute observation $\pm \mathrm{SE}$ ) for agriculture $(n=24)$, open space $(n=72)$, and developed $(n=18)$ land use types.

Kestrels interacted with red-tailed hawks using territorial behavior during the course of three surveys at two developed land use sites and one open space land use site (Figure 8). Other interactions included a Northern mockingbird (Mimus polyglottos) harassing a 
kestrel in an open space land use site, an unknown swallow species mobbing a kestrel in a developed land use site and one survey in which a kestrel flushed when a car approached in an agricultural land use site. The highest number of kestrels (including adults and juveniles) seen in one survey was four, which was at an open space land use site at Bernal Historic Park. In both surveys combined, the highest number of kestrels was five at Laguna Ave followed by four at Coyote Valley Open Space and four at Los Esteros Rd. 


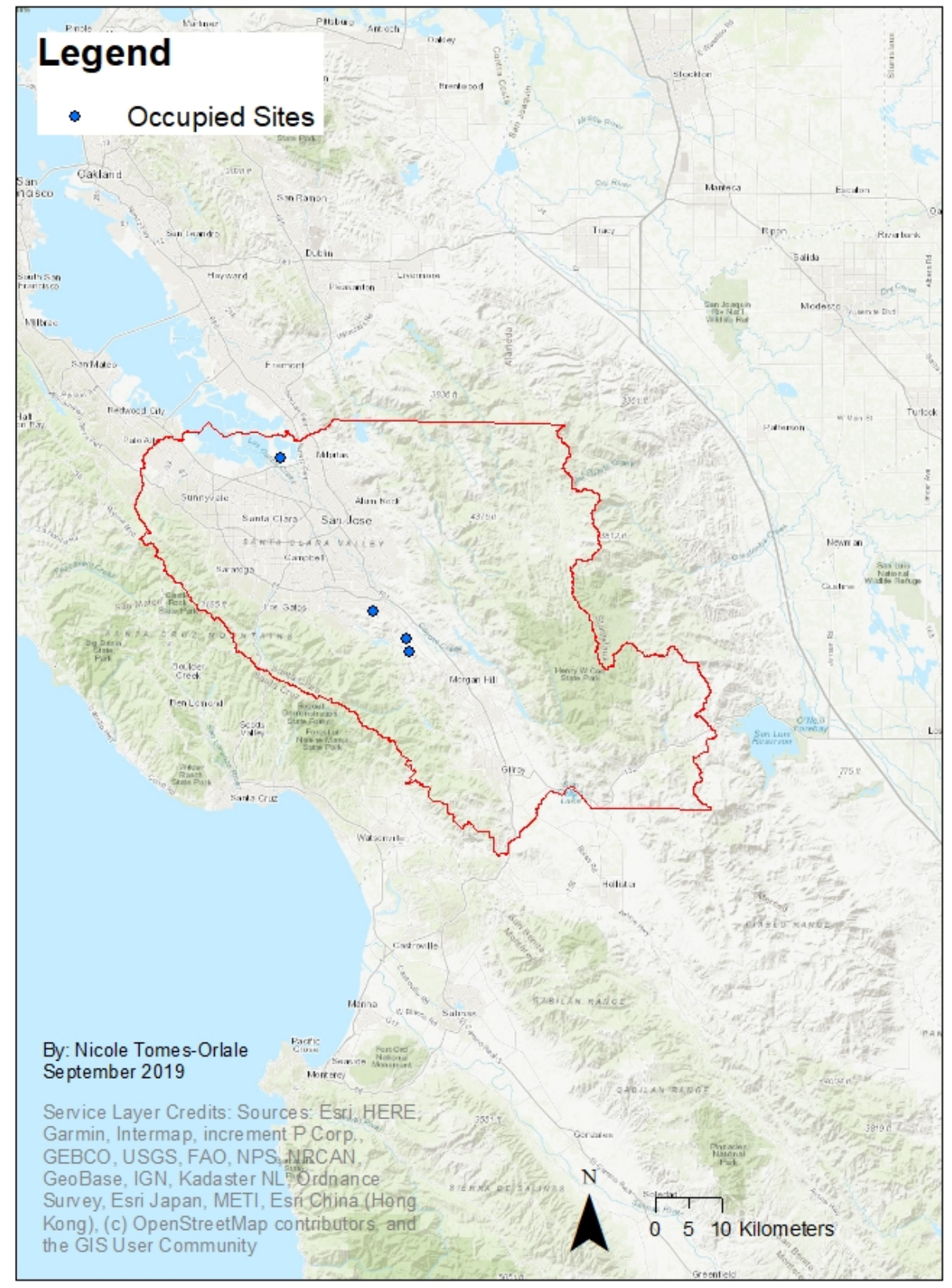

Figure 8. Occupied sites with the highest kestrel counts during two field surveys combined. 


\section{Kestrel Behavior}

Kestrels perched most often on tree branches or snags (17 observations), followed by powerlines or fence lines ( 7 observations), posts (post, sprinkler, nest box; 5

observations), and the ground (1 observation). The behaviors observed during each visit are shown in Table 2.

Table 2

Descriptive Statistics of Kestrel Counts and Behavior

\begin{tabular}{lrrrrrr}
\hline & Foraging & Flyover & Perched & Calling & Hovering & \multicolumn{2}{c}{$\begin{array}{c}\text { Kestrel } \\
\text { Count }\end{array}$} \\
\hline Open Space & 10 & 2 & 16 & 5 & 7 & 28 \\
Agriculture & 6 & 0 & 5 & 0 & 2 & 9 \\
Developed & 2 & 2 & 4 & 1 & 0 & 10 \\
\hline Total & 18 & 4 & 25 & 6 & 9 & 47
\end{tabular}

Note. Total number of kestrels (kestrel count) and number of kestrels exhibiting each behavior recorded in each land use type (Open space, agriculture, developed).

\section{Habitat Types}

Developed, forest, and open water/wetlands habitat types were dominant at sites not occupied by kestrels, while grassland/shrub/scrub and pasture/hay/crops were the two most common habitat types at sites occupied by kestrels (Figure 9). The mean distance to the nearest road in occupied sites was greater than the mean distance to road in unoccupied sites (Occupied; $\bar{X}=179.00 \mathrm{~m}, \pm 56.96$; Unoccupied; $\bar{X}=161.09 \mathrm{~m}, \pm 39.96$ ). The mean elevation in occupied sites for all land uses was $436.09 \mathrm{ft} . \pm 58.35$. 


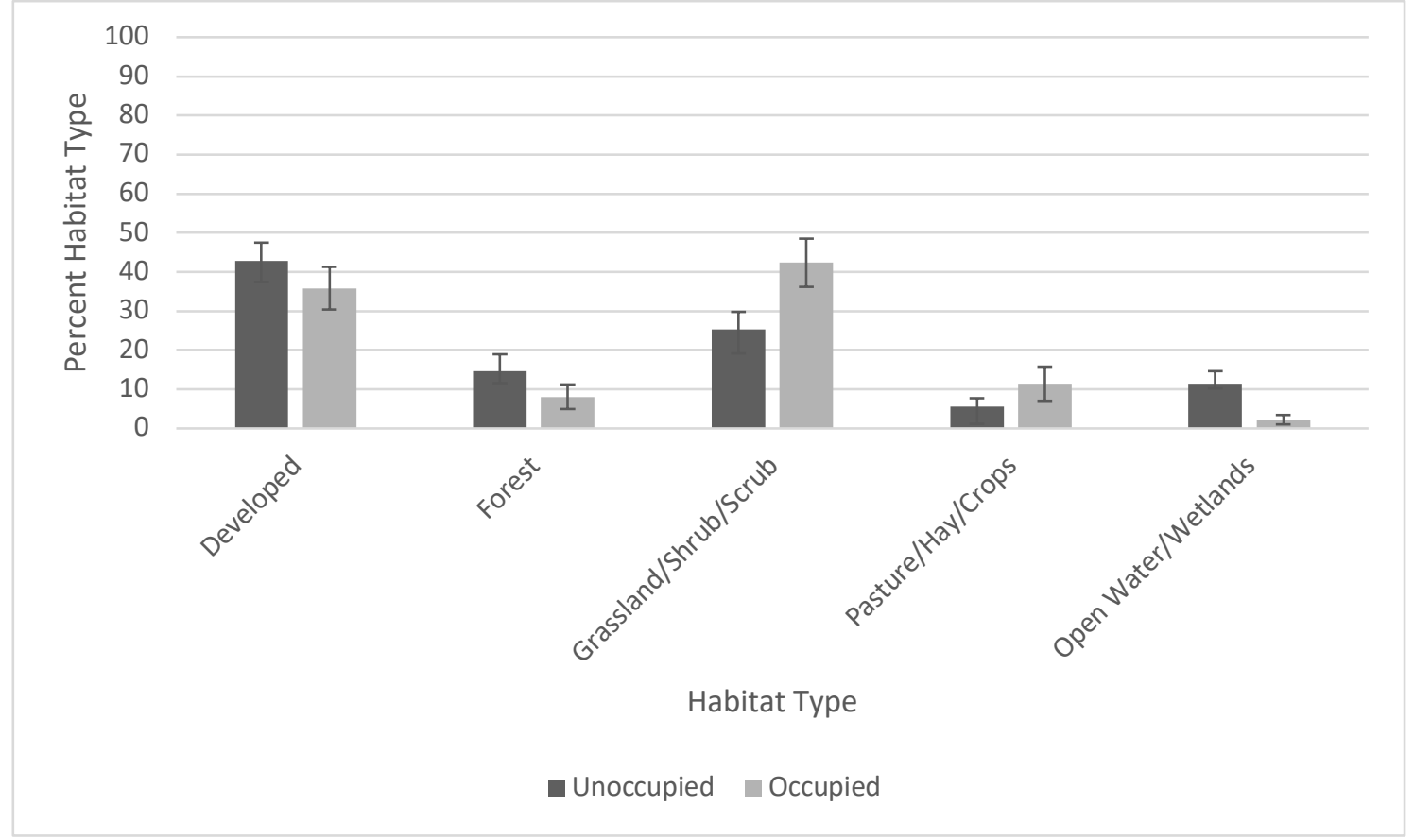

Figure 9. Habitat type percentages (mean \pm SE) for developed, forest, grassland/shrub/scrub, pasture/hay/crops and open water/wetlands in occupied sites and unoccupied sites.

Grassland and pasture/hay/crops were significant predictors of kestrel presence in the logistic regression model (Table 3). 
Table 3

Logistic Regression Analysis of Occupied and Unoccupied Sites

\begin{tabular}{lll} 
Independent Variable & B & P-value \\
\hline Grassland/Shrub/Scrub & 0.033 & $0.01^{*}$ \\
Forest & -0.005 & 0.755 \\
Pasture/Hay/Crops & 0.045 & $0.039^{*}$ \\
Distance to Road & 0 & 0.82
\end{tabular}

Note. Results from logistic regression analysis for unoccupied versus occupied sites with various habitat variables. ${ }^{*} \mathrm{p}<0.05$.

A Mann-Whitney U test confirmed the grassland as a significant predictor $(\mathrm{p}=.034)$.

The percent of grassland was by far the most explanatory variable in the presence of kestrels (Table 4).

Table 4

Mann-Whitney U Analysis of Occupied and Unoccupied Sites

\begin{tabular}{ll}
\hline Habitat Type & p-value \\
\hline Distance to Road & 0.800 \\
Developed & 0.431 \\
Forest & 0.864 \\
Grassland/Shrub/Scrub & $0.034^{*}$ \\
Pasture/Hay/Crops & 0.204 \\
Open water/Wetlands & 0.317
\end{tabular}

Note. Comparison of the amount of habitat type in the buffer between kestrel unoccupied versus occupied sites with a Mann-Whitney U analysis. ${ }^{*} \mathrm{p}<0.05$. 
There was no difference between the three land uses with respect to percent of grassland in each land use type (Kruskal-Wallis $=5.378, \mathrm{df}=2, \mathrm{p}=.068$; Grassland; $\bar{X}=31.8912082, \pm 28.409$ ), although open space was more than double that of agriculture and approximately a third greater than developed land use sites (Figure 10).

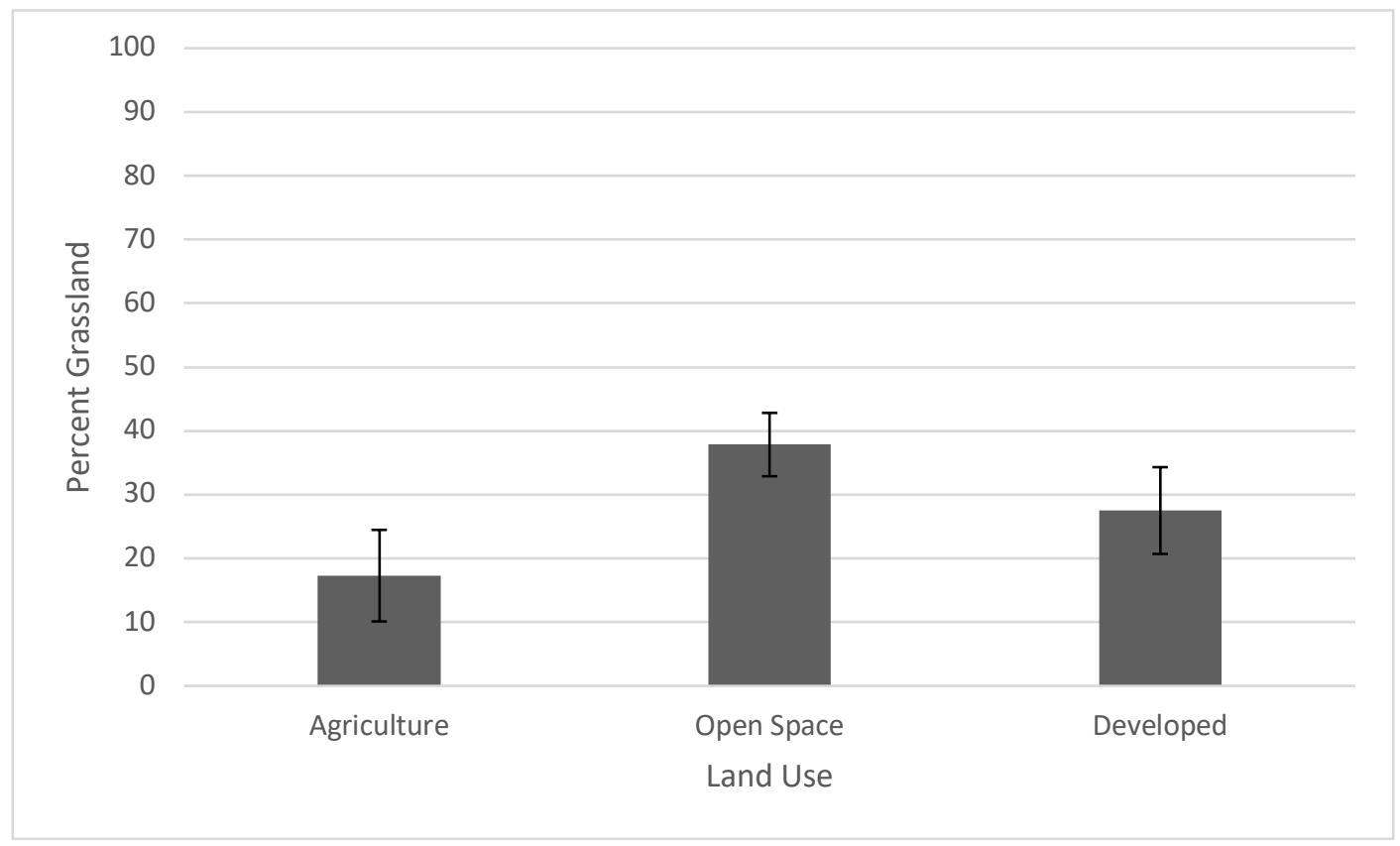

Figure 10. Grassland percentage in agriculture $(\mathrm{n}=12)$, open space $(\mathrm{n}=36)$ and developed $(\mathrm{n}=9)$ land uses.

\section{Nest Box Habitat Variables}

Percent cover of developed, forest, and open water/wetlands was similar in occupied sites and nest box sites. At nest box sites, there was greater average percent cover of grasslands and a lower level of pasture/hay/crops compared to occupied sites in this study, however, not statistically significant (Figure 11). The mean distance to road was greater in nest box sites compared to the occupied sites (Occupied: $\bar{X}=179.00 \mathrm{~m}$; Nest box: $\bar{X}=244.89 \mathrm{~m}, \pm 114.32$ ). 


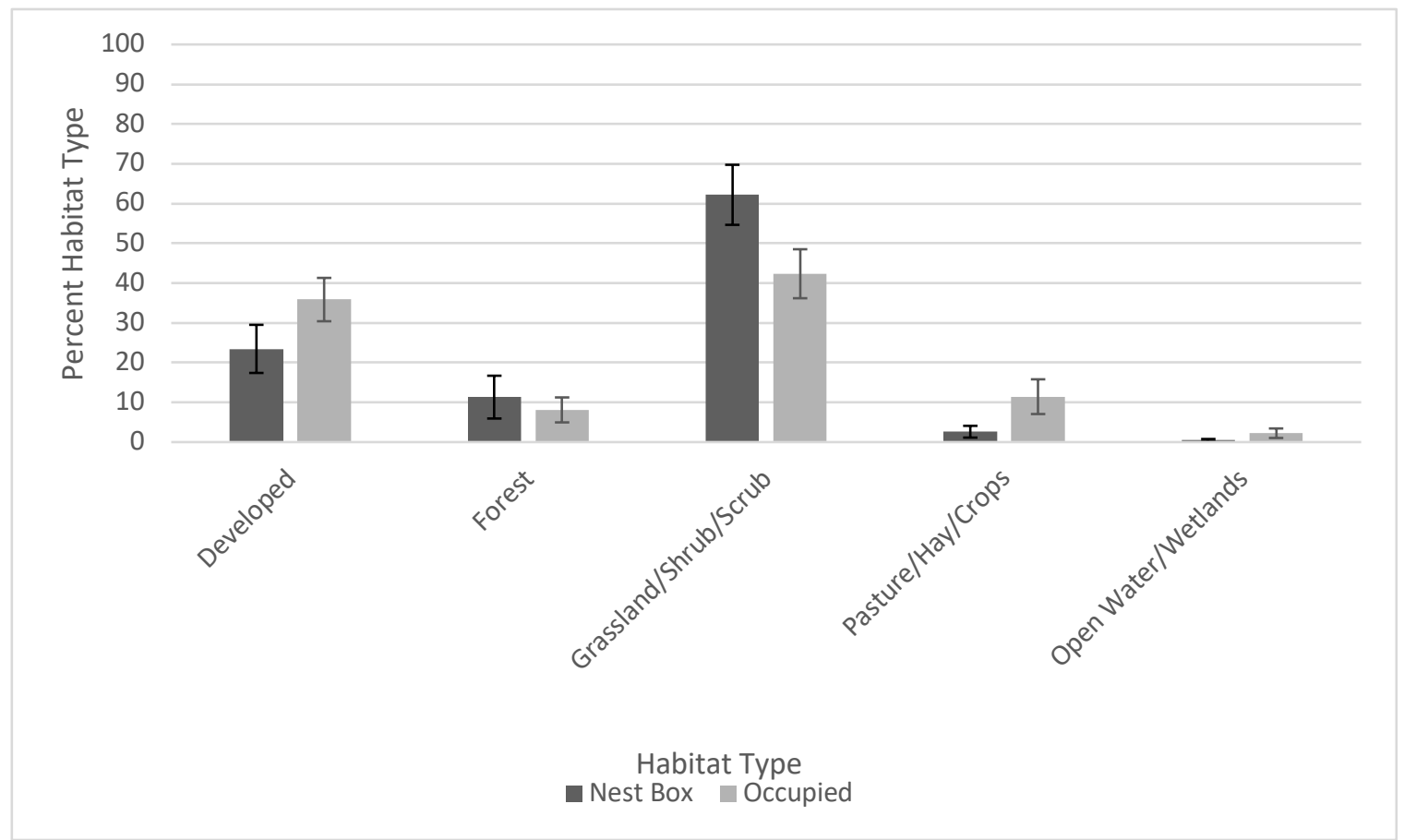

Figure 11. Habitat type percentages (mean $\pm \mathrm{SE}$ ) for developed, forest, grassland/shrub/scrub, pasture/hay/crops and open water/wetland in occupied sites and nest box sites. 


\section{Discussion}

The key goal of this study was to determine the qualities of habitat occupied by American kestrels during the breeding season in agriculture, developed and open space land use types in Santa Clara County, CA. Results showed that occupied kestrel habitat had a much greater percent of grassland than unoccupied habitat regardless of land use. Developed land use in this study was within an urban matrix with grasslands, which could indicate why there was no difference in the amount of grassland between the three land uses. Other studies support the importance of grasslands to kestrels. In Central Missouri, kestrels foraged most efficiently in disturbed grasslands and foraged least efficiently in old fields and croplands (Toland, 1987). Kestrel occupancy was positively associated with grassland cover in St. Louis, Missouri as well based on call broadcast surveys in business park landscapes (Hogg \& Nilon, 2014). Smallwood et al. (2009) also found that in $56.4 \mathrm{~m}$ radius nest box plots in New Jersey, the lack of woody canopy was the best predictor of kestrel use of a site. Land use/land cover categories that are suitable for foraging by kestrels were considered cropland and pastureland, agricultural wetlands, herbaceous wetlands, old field with $25 \%$ brush, other agriculture, recreational land, orchards/vineyards/nurseries/horticulture areas, school athletic fields, managed wetlands within lawns and confined feeding operations (Smallwood, 1987: Smallwood et al., 2009).

Similar to findings in other regions, kestrels in Santa Clara County were found frequently in the pasture/hay/crop habitat type. A study in boreal habitat in $800 \mathrm{~m}$ radius plots found kestrels were attracted to nest sites with a greater proportion of available 
agricultural habitats. However, hatching success was almost $20 \%$ lower than in areas without agriculture, indicating that this area might be an ecological trap for kestrels because human disturbance in agricultural habitats is ultimately harmful to kestrels (Touihri et al., 2019).

In this thesis research, the percent of the "developed" habitat type, did not differ between occupied and unoccupied sites. However, research indicates that developed land uses may have negative effects on kestrels. Strasser and Heath (2013) showed that the proximity to large busy roads and developed areas negatively affected kestrel reproduction and acted as a stressor promoting nest abandonment. As disturbance increased in the vicinity of nests, as measured by increasing size and traffic of roads and increasing levels of developed landscape, so did the probability of reproductive failure (Strasser \& Heath, 2013).

In addition to the human disturbance associated with urban land uses, this study found that the abundance of raptors was much greater at developed sites than in agricultural and open space sites. This density of raptors could be partly due to availability of prey that are found within urban areas. For example, Palomino and Carrascal (2007) found that urban development had a positive effect on the Booted eagle (Hieraaetus pennatus), likely due to an increase in the availability of its potential prey within urban areas. Large raptors are likely to reduce the prey available to kestrels and exert increased predator pressure on kestrels in urban land use compared to agricultural and open space areas.

Perch types and location can be important to raptors, such as kestrels, that will dive from perches to capture prey. In this study, kestrels used tree branches, snags, 
powerlines/fence lines, posts (post sprinkler, nest box) and the ground for prey capture. Most frequent perches were tree branches and snags. However, due to unquantified differences in perch availability at each site, the perch type was not analyzed. Kestrels exhibited perching behavior more than other behaviors in the field. In Boone County, Missouri, kestrels spent an average of $75 \%$ of the day hunting; a total of $63 \%$ of time kestrels were perch hunting, $7 \%$ was hover hunting, $3.5 \%$ was changing perch sites and $1.5 \%$ was in horizontal pursuit flight (Toland, 1987). Hunting efficiency was highest during perch hunting (Toland, 1987). A study in Arkansas showed that kestrels used wires significantly more than any other of the five perch types defined (top of utility pole, crossbeam of utility pole, utility wire, tree or other (on the ground, signs, farming equipment) (Bobowski, Rolland, \& Risch, 2014). During three surveys in this study, kestrels used territorial behavior towards red-tailed hawks. Habitat use and prey preferences are similar between the kestrels and red-tailed hawks (Bobowski et al., 2014). Perch site availability may affect the raptors' choice of foraging patches. Kestrels may find wires as more suitable perch sites due to having smaller talons than red-tailed hawks (Bildstein, 1987).

The habitat qualities preferred by kestrels can help guide kestrel nest box programs, at least one of which existed in Santa Clara County during the period of this study. Grassland was the most dominant habitat type around nest boxes used by kestrels, which is the most essential habitat type for kestrels. However, pasture/hay/crop may have been lower for the nest box sites versus other occupied sites in Santa Clara County. Smallwood et al., (2009) found that nest boxes that were chosen by kestrels were surrounded by 
significantly greater coverage of cropland and pastureland than nest boxes not occupied by kestrels. Nest boxes occupied by kestrels were associated with significantly less closed deciduous forest than nest boxes not occupied by kestrels. Research on nesting American kestrels in Berks and Lehigh Counties, Pennsylvania, from 1987-1991 found that frequently used boxes were associated with extremely open habitat dominated by herbaceous vegetation (Rohrbaugh \& Yahner, 1997). Nesting kestrels avoided using boxes associated with dense habitats, such as late-successional old fields. Frequently used nest boxes were farther from forested areas than unused boxes.

This research confirms the importance of grassland habitat to kestrels in Santa Clara County, especially in open space land uses and underscores the need to permanently protect such habitats. Grassland habitat is declining throughout the U.S. and protecting grasslands, will protect not only kestrels but a range of other species. 


\section{Recommendations}

This study indicates that kestrels chose sites based on grassland and pasture/hay habitat, therefore, conserving areas with grassland and less disturbed pasture/hay/crop habitat type would be beneficial for them at an average elevation of $436.09 \mathrm{ft}$. Adding more nest boxes to grassland and agricultural land cover and in open space land uses that maintain a distance from roads could possibly attract more kestrels to the nest boxes for future studies. Because American kestrel populations tend to be nest-site-limited, the introduction of nest boxes typically results in a rapid increase in the number of pairs that breed in these boxes (Hamerstrom \& Hart, 1973; Bloom \& Hawks, 1983; Toland \& Elder, 1987; Smallwood \& Collopy 2009; Smallwood et al., 2009).

Future studies of American kestrel habitat use should investigate the role of past and projected land use change on kestrel distribution and abundance. In addition, adding more sites and nest boxes with strategic monitoring of a range of factors such as reproduction and association with land cover and patch size would be beneficial to understand habitat selection in this county. Small tracking devices can be used to quantify movement and survival, factors that are increasingly important to understand as this raptor is declining in this area and around the U.S. Due to the small number of kestrels found during this study, it is unknown whether development has impacted kestrel occupancy. Future research should include multiple field seasons for an increased sample size of kestrels to increase statistical power. 


\section{References}

Beedy, E.C., and Pandolfino, E.R. (2013). Birds of the Sierra Nevada. Berkeley. University of California Press.

Berry, M. E., Bock, C. E., Haire, S. L. (1998). Abundance of diurnal raptors on open space grasslands in an urbanized landscape. Condor, 100, 601-608.

Bildstein, K.L., Collopy, M. (1987). Hunting behavior of Eurasian (Falco tinnunculus) and American kestrels (F. sparverius): A review, p. 66-82. In D.M. Bird and B. Reed [Eds.], The Ancestral Kestrel. Anne de Bellevue, Quebec: Raptor Research Foundation, Inc. and Macdonald Raptor Research. Centre of McGill Univ., Ste. U.S.A.

Bird, D.M. and Palmer, R.S. (1988). American kestrel. In R.S. Palmer [Eds.], Handbook of North American birds: Diurnal raptors (Part 2, Vol. 5, pp. 253290) New Haven, CT: Yale Univ. Press U.S.A.

Bloom, F.H. and Hawks, S. J. (1983). Nest box use and reproductive biology of the American kestrel in Lassen County, California. Journal of Raptor Research, 17, 9-14.

Bobowski, M. M., Rolland, V., and Risch, T. S. (2014). Abundance and distribution of overwintering red-tailed hawks and American kestrels in an agricultural landscape in Northeastern Arkansas. Journal of Raptor Research, 48, 273-279.

Bousman, B. (2007). Breeding bird atlas of Santa Clara County California, Santa Clara Valley Audubon Society. Santa Clara Valley Audubon Society, CA.

Brouse, P. (1999). Twenty-year change in the raptor community in Northern Utah during the nonbreeding season. Journal of Raptor Research, 33, 317-322.

Burnham, W. A., Whitacre, D. F., and Jenny, J. P. (1990). Progress report III. Maya project: use of raptors as environmental indices for design and management of protected areas and for building local capacity for conservation in Latin America. The Peregrine Fund, Boise, Idaho.

Cade, T. J. (1982). The falcons of the world. New York: Comstock/Cornell Univ. Press.

Craighead, J. J., and Craighead, F.C. (1956). Hawks, owls, and wildlife. Stackpole Co., Harrisburg, Penn., and Wildlife Management Institute, Washington, D.C.

Cringan, A. T., and Horak, G.C. (1989). Effects of urbanization on raptors in the Western United States, p.219-228. In B.G. Pendleton [Eds.], Western Raptor Management Symposium and Workshop. National Wildlife Federation, Washington D.C. 
Czech, B., Krausman, P.R. and Devers, P.K. (2000). Economic associations among causes of species endangerment in the United States. BioScience, 50, 593-601.

Dolman, P.M. and Sutherland, W.J. (1995). The response of bird populations to habitat loss. Ibis, 137, 538-546.

Dowall (1984). The suburban squeeze: land conversion and regulation in the San Francisco Bay Area. University of California Press.

Estrella, R.R., Donazar, J.A., Hiraldo, F. (1998). Raptors as indicators of environmental change in the scrub habitat of Baja California Sur, Mexico. Conservation Biology, 12, 921-925.

Estrella, R.R. (2007). Land use changes affect distributional patterns of desert birds in the Baja California peninsula, Mexico. Diversity and Distributions, 13(6), 877-889.

Ewers, R.M. and Didham, R.K. (2005). Confounding factors in the detection of species responses to habitat fragmentation. Biological Reviews of the Cambridge Philosophical Society, 81, 117-142.

Farmer, C. J. and Smith, J. P. (2009). Migration monitoring indicates widespread declines of American Kestrels (Falco sparverius) in North America. Journal of Raptor Research, 43, 63-273.

Greene, H. W. (1988). Species richness in tropical predators. In F. Almeda and C. Pringle (Eds), Tropical rainforests: diversity and conservation (pp. 259-274). California Academy of Science, San Francisco.

Grossinger, R.M., Striplen, C.J., Askevold, R.A., Brewster, E., Beller E.E. (2007). Historical landscape ecology of an urbanized California Valley: wetlands and woodlands in the Santa Clara Valley. Landscape Ecology, 22, 103-120.

Hamerstrom, E N. and Hart, J. (1973). Nest boxes: an effective management tool for kestrels. Journal of Wildlife Management, 37, 400-403.

Heath, J. A., Steenhof, K., Foster, M.A. (2012). Shorter migration distances associated with higher winter temperatures suggest a mechanism for advancing nesting phenology of American kestrels Falco sparverius. Journal of Avian Biology, 43, 376384. 
Herkert, J.R. (1994). The effects of habitat fragmentation on Midwestern grassland bird communities. Ecological Applications, 4, 461-471.

Hogg, J.R., Nilon, C. (2015). Habitat associations of birds of prey in urban business parks. Urban Ecosystems, 18, 267-284.

Korpimaki, E. (1984). Population dynamics of birds of prey in relation to fluctuations in small mammal populations in western Finland. Annates Zoologici Fennici, 21, 287293.

Korpimaki, E. (1986). Predation causing synchronous decline phases in microtine and shrew populations in western Finland. Oikos, 46, 124-127.

Korpimäki, E. \& Norrdahl, K. (1991). Numerical and functional responses of kestrels, short-eared owls and long eared owls to vole densities. Ecology, 72(3).

Kowarik, I. (1995). On the role of alien species in urban flora and vegetation. $S P B$ Academic, 85-103.

Laurance, W.F. (2008). Theory meets reality: How habitat fragmentation research has transcended island biogeographic theory. Biological Conservation, 141(7), 17311744.

Luniak, M. (1994). The development of bird communities in new housing estates in Warsaw. Memorabilia Zoologica, 49, 257-267.

Martin, J. Kitchens, W. Cattau, C. Oli, M. (2008). Relative importance of natural distributions and habitat degradation on snail kite population dynamics. Endangered Species Research, 6, 25-39.

Macarthur, R. and Wilson, E.O. (1967). The theory of island biogeography. Princeton University Press.

Marzluff, J.M. (2001). Worldwide urbanization and its effects on birds. Avian Ecology and Conservation in an Urbanizing World, 19-47.

McClure, C. J. W., Schulwitz, S.E., Van Buskirk, R., Pauli, B.P., Heath, J.A. (2017). Commentary: Research recommendations for understanding the decline of American Kestrels (Falco sparverius) across much of North America. Journal of Raptor Research, 51(4), 455-464.

McKinney, M.L. (2002). Urbanization, biodiversity, and conservation. American Institute of Biological Sciences, 52, 883-890. 
Newton, I. (1979). Population ecology of raptors. Buteo Books. Vermillion, SD: USA.

Olendorff, R. R. (1984). Land management for raptor conservation 1984-2034.

Olendorff, R. R., Bibles, D. D., Dean, M.T., Haugh, J.R. and Kochert, M.N. (1989). Raptor habitat management under the U.S. Bureau of Land Management MultipleUse Mandate. Raptor Research Report, 8, 1-80.

Owens, I.P.F and Bennet, P.M. (2000). Ecological basis of extinction risk in birds: habitat loss versus human persecution and introduced predators. Proceedings of the National Academy of Sciences of the United States of America, 97, 12 144-12148.

Pandolfino, E. R., Herzog, M.P., Hooper, S.L., Smith, Z. (2011). Winter habitat associations of diurnal raptors in California's central valley. Western Birds, 42, 6284.

Palomino, D., and Carrascal, L. M. (2007). Habitat associations of a raptor community in a mosaic landscape of Central Spain under urban development. Landscape and Urban Planning, 83, 268-274.

Paviour, J. (2013). Key factors that influence breeding performance in raptors. The Plymouth Student Scientist, 6, 386-399.

Pautasso, M. (2012) Observed impacts of climate change on terrestrial birds in Europe: an overview. Italian Journal of Zoology, 79, 296- 314.

Pearlstine E.V., Mazzotti, F.J., and Kelly, M.H. (2006). Relative distribution and abundance of wintering raptors in agricultural and wetland landscapes of south Florida. Journal of Raptor Research, 40, 81-85.

Potter, C. (2015). A case study of forest and woodland habitat loss to disturbance and development in an ex-urban landscape: Santa Clara County, CA 1999-2009, Current Urban Studies, 3(01), 18-24.

Roberson, D. (1993). Red-shouldered hawk. In D. Roberson and C. Tenney (Eds.), Atlas of the breeding birds of Monterey County, California. Monterey (pp.9697). Monterey, CA: Peninsula Audubon Society.

Rohrbaugh, R.W., JR. and Yahner, JR, RH. (1997). Effects of macrohabitat and microhabitat on nest-box use and nesting success of American kestrels. Wilson Bulletin, 109, 410-423. 
Rullman, S., and Marzluff, J.M. (2014). Raptor presence along an urban-wildland gradient: Influences of prey abundance and land cover. Journal of Raptor Research, 48, 257-272.

Senner, S.E. C.M. White, and J.R. Parrish (Eds). (1984). Raptor conservation in the next 50 years. Raptor Research Foundation, Raptor Research Rep. No. 5 Press Publication, Provo, UT.

Shave M.E. and Lindell C.A. (2017) American kestrels occupying nest boxes in Michigan cherry orchards show high reproductive rates and tolerance of monitoring. Journal of Raptor Research, 51, 50-60.

Sergio, F., Caro, T., Brown, D., Clucas, B., Hunter, J., Ketchum, J., McHugh, K. \& Hiraldo, F. (2008). Top predators as conservation tools: ecological rationale, assumptions, and efficacy. Annual Review of Ecology, Evolution, and Systematics, 39, 1-19.

Smallwood, J.A. (1987). Sexual segregation by habitat in American kestrels (Falco sparverius) wintering in south- central Florida: vegetative structure and responses to differential prey availability. Condor, 89, 842-849.

Smallwood, J.A. (1988). A mechanism of sexual segregation by habitat in American kestrels (Falco sparverius) wintering in southcentral Florida. Auk, 105, 36-46.

Smallwood, J.A., and D.M. Bird (2002). American kestrel (Falco sparverius). In A. Poole (Ed.), Birds of North America Online. Ithaca, NY: Cornell Lab of Ornithology.

Smallwood, J.A., Collopy, M.W. (2009). Southeastern American kestrels respond to an increase in the availability of nest cavities in North-Central Florida. Journal of Raptor Research, 43, 291-300.

Smallwood, J. A., Causey, M.F., Mossop, D.H., Klucsarits, J.R., Robertson, B., Robertson, S., Mason, J., Maurer, M.J., Melvin, R.J., Dawson, R.D., Bortolotti, G.R., Parrish, J.W. Jr., Breen, T.F., Boyd, K. (2009). Why are American kestrel (Falco Sparverius) populations declining in North America? Evidence from nest-box programs. Journal of Raptor Research, 43, 274-282.

Smith, S.H., Steenhof, K., McClure, C.J.W., Heath, J.A. (2016). Earlier nesting by generalist predatory bird is associated with human responses to climate change. Journal of Animal Ecology, 86, 98-107.

Shuford, W. D. (1993). The Marin County Breeding Bird Atlas: A Distributional and Natural History of Coastal California Birds. California Avifauna Series 1. Bushtit Books, Bolinas, CA. 
Strasser, E. H., and Heath, J. A. (2013). Reproductive failure of a human-tolerant species, the American kestrel, is associated with stress and human disturbance. Journal of Applied Ecology, 50, 912-919.

Steenhof, K. and Peterson, B.E. (2009). American kestrel reproduction in Southwestern Idaho: annual variation and long-term trends. Journal of Raptor Research, 43, 283 290.

Stout, W. E., Temple, S.A., and Papp, J.M. (2006). Landscape correlates of reproductive successfor an urban-suburban red-tailed hawk population. The Journal of Wildlife Management, 70, 989-997.

Taylor, R. J. (1984). Predation. Chapman and Hall, New York.

Terborgh, J. (1992). Maintenance of diversity in tropical forests. Biotropica, 24, 283292.

Toland, B. and Elder, W.H. (1987). Influence of nest-box placement and density on abundance and productivity of American kestrels in central Missouri. Wilson Bullentin, 99, 712-717.

Toland, B.R. (1987). The effect of vegetative cover on foraging strategies, hunting success and nesting distribution of American kestrels in Central Missouri. Journal of Raptor Research, 21, 14-20.

Touhiri, M., Seguey, M., Imbeau, L., Mazerolle, M.J. Bird, D. (2018). Effects of landscape composition on habitat selection and breeding success of American kestrels in a boreal context, do extensive agricultural lands act as ecological traps? Agriculture, Ecosystems and Environment, 272, 146-154.

Vale, T. R. and Vale, G.R.. (1976). Suburban bird populations in west-central California. Journal of Biogeography, 3, 157-165.

Valkama J., Korpomaki E., Tolonen P. (1995). Habitat utilization, diet and reproductive success in the kestrel in a temporally and spatially heterogenous environment. Ornisfennica, 71, 49-61.

Wilcove, D.S., McLellan, C.H. and Dobson, A.P. (1986). Habitat fragmentation in the temperate zone. Fish and Wildlife Service, 237-256.

Wilson, M.C. 2016 Habitat fragmentation and biodiversity conservation: key findings and future challenges. Landscape Ecology, 31(2), 219-227. 
Wood, D. A., Bui, T.D., Overton, C.T., Vandergast, A.G., Casazza, M.L., Hull, J.M., Takekawa, J.Y. (2017). A century of landscape disturbance and urbanization of the San Francisco Bay Region affects the present-day genetic diversity of the California Ridgway's rail (Rallus obsoletus obsoletus). Conservation Genetics, 18, 131-146.

Wu, J.G. (2013). Key concepts and research topics in landscape ecology revisited: 30 years after the Allerton Park workshop. Landscape Ecology, 28, 1-11. 


\section{Appendix A}

Land Cover Variables from NLCD 2011 Legend

Value

Classification Description

11 Open Water- areas of open water, generally with less than $25 \%$ cover of vegetation or soil.

12 Perennial Ice/Snow- areas characterized by a perennial cover of ice and/or snow, generally greater than $25 \%$ of total cover.

21 Developed, Open Space- areas with a mixture of some constructed materials, but mostly vegetation in the form of lawn grasses. Impervious surfaces account for less than $20 \%$ of total cover. These areas most commonly include large-lot single-family housing units, parks, golf courses, and vegetation planted in developed settings for recreation, erosion control, or aesthetic purposes.

22 Developed, Low Intensity- areas with a mixture of constructed materials and vegetation. Impervious surfaces account for $20 \%$ to $49 \%$ percent of total cover. These areas most commonly include single-family housing units.

23 Developed, Medium Intensity- areas with a mixture of constructed materials and vegetation. Impervious surfaces account for $50 \%$ to $79 \%$ of the total cover. These areas most commonly include single-family housing units.

24 Developed High Intensity- highly developed areas where people reside or work in high numbers. Examples include apartment complexes, row houses and commercial/industrial. Impervious surfaces account for $80 \%$ to $100 \%$ of the total cover.

31 Barren Land (Rock/Sand/Clay) - areas of bedrock, desert pavement, scarps, talus, slides, volcanic material, glacial debris, sand dunes, strip mines, gravel pits and other accumulations of earthen material. Generally, vegetation accounts for less than $15 \%$ of total cover.

41 Deciduous Forest- areas dominated by trees generally greater than 5 meters tall, and greater than $20 \%$ of total vegetation cover. More than $75 \%$ of the tree species shed foliage simultaneously in response to seasonal change.

42 Evergreen Forest- areas dominated by trees generally greater than 5 meters tall, and greater than $20 \%$ of total vegetation cover. More than $75 \%$ of the tree species maintain their leaves all year. Canopy is never without green foliage. 
43 Mixed Forest- areas dominated by trees generally greater than 5 meters tall, and greater than $20 \%$ of total vegetation cover. Neither deciduous nor evergreen species are greater than $75 \%$ of total tree cover.

51 Dwarf Scrub- Alaska only areas dominated by shrubs less than 20 centimeters tall with shrub canopy typically greater than $20 \%$ of total vegetation. This type is often co-associated with grasses, sedges, herbs, and non-vascular vegetation.

52 Shrub/Scrub- areas dominated by shrubs; less than 5 meters tall with shrub canopy typically greater than $20 \%$ of total vegetation. This class includes true shrubs, young trees in an early successional stage or trees stunted from environmental conditions.

71 Grassland/Herbaceous- areas dominated by gramanoid or herbaceous vegetation, generally greater than $80 \%$ of total vegetation. These areas are not subject to intensive management such as tilling, but can be utilized for grazing.

72 Sedge/Herbaceous- Alaska only areas dominated by sedges and forbs, generally greater than $80 \%$ of total vegetation. This type can occur with significant other grasses or other grass like plants, and includes sedge tundra, and sedge tussock tundra.

73 Lichens- Alaska only areas dominated by fruticose or foliose lichens generally greater than $80 \%$ of total vegetation.

74 Moss- Alaska only areas dominated by mosses, generally greater than $80 \%$ of total vegetation.

81 Pasture/Hay-areas of grasses, legumes, or grass-legume mixtures planted for livestock grazing or the production of seed or hay crops, typically on a perennial cycle. Pasture/hay vegetation accounts for greater than $20 \%$ of total vegetation.

82 Cultivated Crops- areas used for the production of annual crops, such as corn, soybeans, vegetables, tobacco, and cotton, and also perennial woody crops such as orchards and vineyards. Crop vegetation accounts for greater than $20 \%$ of total vegetation. This class also includes all land being actively tilled. 
90 Woody Wetlands- areas where forest or shrubland vegetation accounts for greater than $20 \%$ of vegetative cover and the soil or substrate is periodically saturated with or covered with water.

95 Emergent Herbaceous Wetlands- Areas where perennial herbaceous vegetation accounts for greater than $80 \%$ of vegetative cover and the soil or substrate is periodically saturated with or covered with water. 


\section{Appendix B}

\section{Measured Variables}

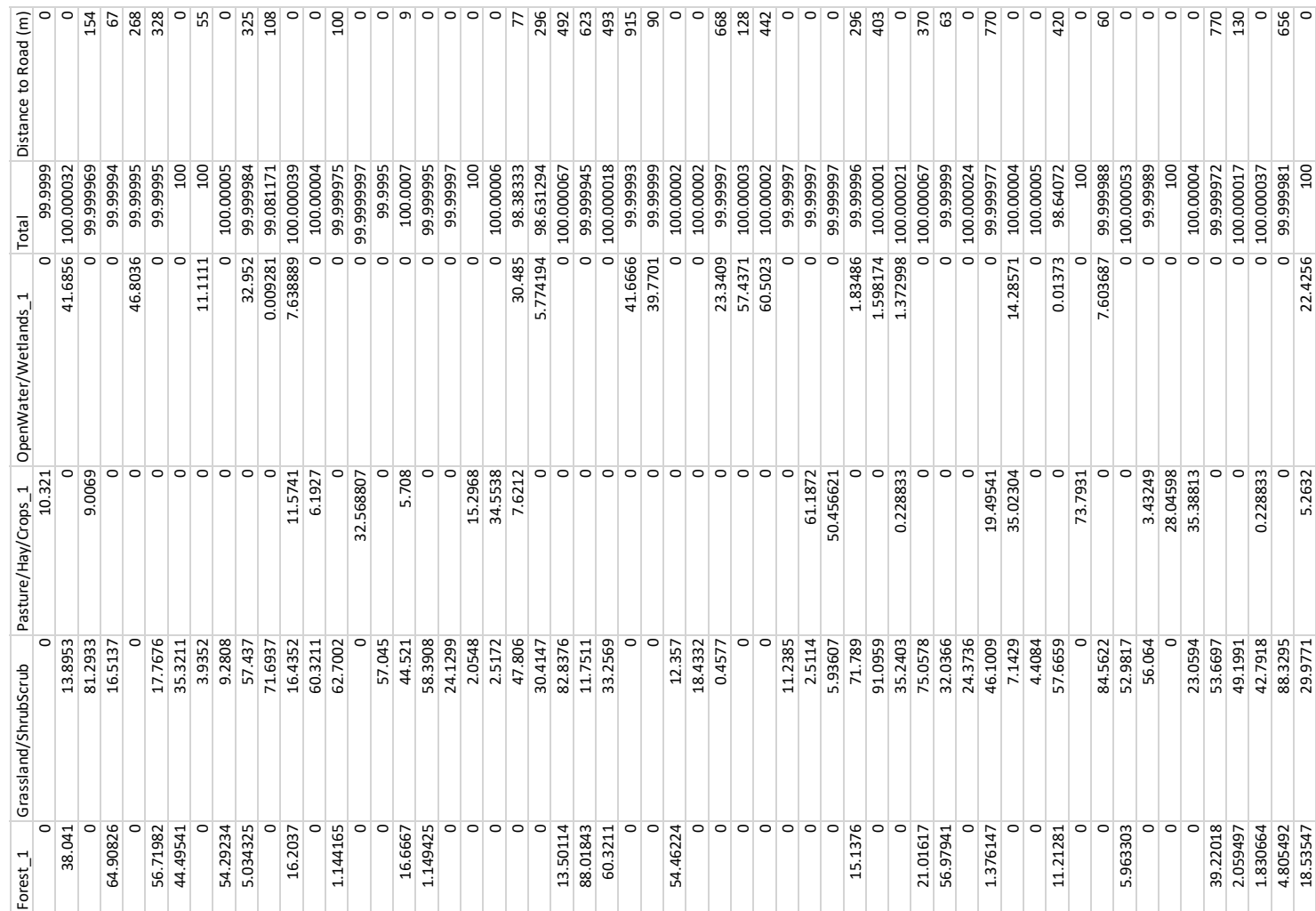

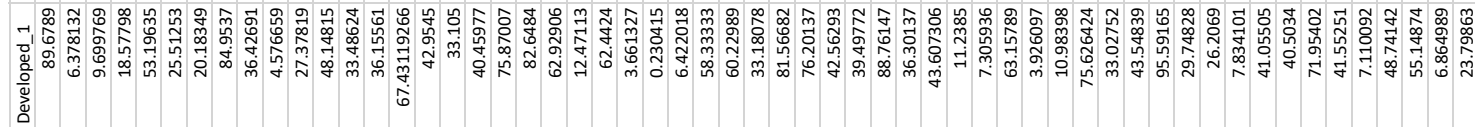

$\overline{\mathrm{g}}$

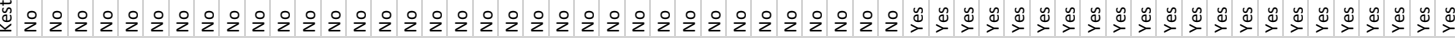

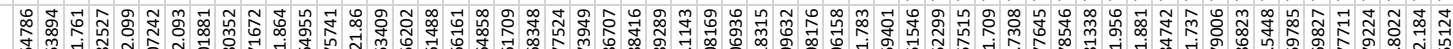
与

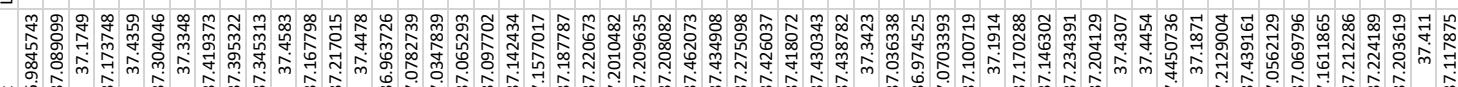

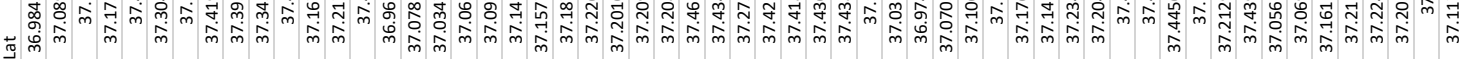

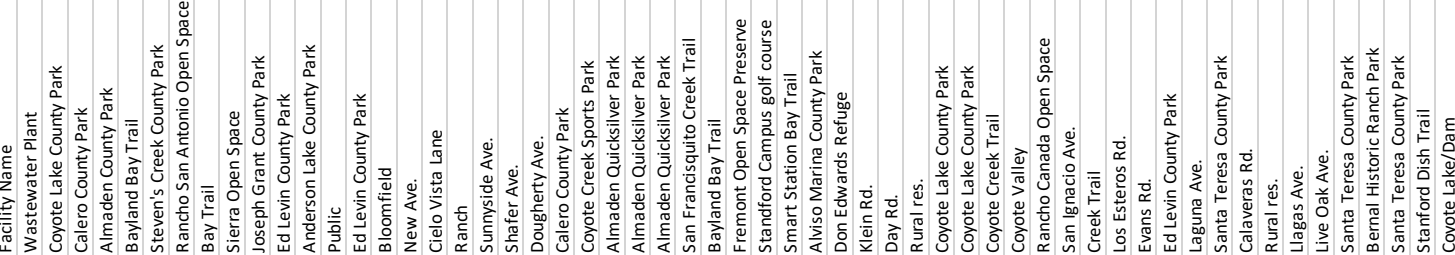

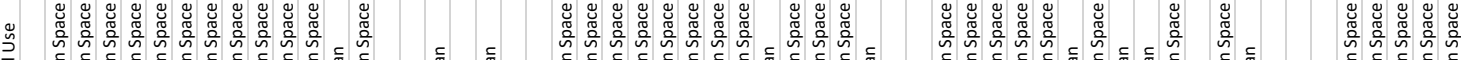

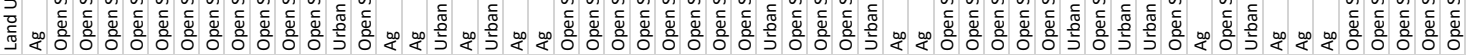

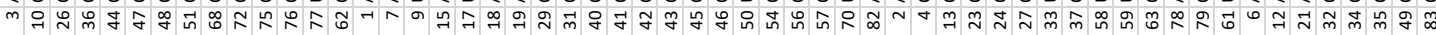

$\stackrel{9}{9}$ 